\title{
Adana'da Turizm Sektörünün Bölgesel Kalkınmadaki Rolü*
}

\author{
Sibel OĞUZ**, Özgür KIZILDEMİR ${ }^{* * *}$, Nuray EKER ${ }^{* * * *}$
}

Öz

20. yüzyılın ikinci yarısından itibaren turizm, dünya ekonomisinde en hızlı gelișen ve genişleyen endüstrilerden biri haline gelmiştir (Çımat ve Bahar, 2003; UNWTO, 2014). Birleşmiş Milletler Dünya Turizm Örgütü (UNWTO)'nün 2016 yllında yayınlanan raporuna göre, uluslararası seyahatlere katılan kişi sayısının 1 milyarı geçtiği, bu hareketler sonucunda 1 trilyon doların üzerinde bir gelir elde edildiği anlaşılmaktadır (UNWTO, 2016). Bu araştırma, Adana destinasyonun mevcut turizm potansiyelinin incelenmesi ile başlayıp, turizm destinasyonu kapsamında turistlerin harcamaları incelenmiştir. Yapılan bu turistik harcamaların destinasyondaki ekonomik etkilerine bakılarak bölgesel kalkınmadaki rolü değerlendirilmiștir. Bu araștırmanın amacı; bölgesel kalkınmada Adana ekonomisine turizm endüstrisinin ekonomik katkılarını değerlendirmektir. Adana'ya gelen turist sayısının yıllar itibariyle artış göstermesi il ekonomisine turizmin katkısının ölçülmesi gerekliliğini ortaya koymaktadır. Çalışma kapsamında 396'sı T.C. vatandaşı olmak üzere Adana ilini ziyaret eden 600 turiste bölgesel kalkınma anketi uygulanmıştır. Araştırma sonuçlarına göre kişi başı ortalama turist harcaması 2232 TL'dir. Gelen turist sayısının ortalama kişi başına harcamayla çarpılması sonucu yaklaşık 2,44 milyar TL/642 milyon $\$(1$ \$=3,8 TL) doğrudan Adana ekonomisine katkı yaptığı görülmektedir. Adana'da turizmin geliştirilmesi bölgeye ekonomik katkılar sunacak, bölgedeki ulaşım ağlarının, alt yapı ve üst yapının, turizm ișletmelerinin, istihdamın ve bölgedeki diğer sektörlerin gelișimine katkılar sağlayacaktır.

Anahtar Kelimeler: Turizm Sektörü, Turistik Harcama, Ekonomik Etki, Bölgesel Kalkınma, Adana.

\section{Özgün Araștırma Makalesi (Original Research Article)}

Geliş/Received: 10.08 .2018

Kabul/Accepted: 21.08 .2018

DOI: http://dx.doi.org/10.17336/igusbd.431644

*Adana Bilim ve Teknoloji Üniversitesi, Bilimsel Araştırma Projeleri Koordinasyon Birimi tarafindan desteklenmiştir (Proje No: 17117001).

${ }^{* *}$ Sorumlu Yazar, Dr. Öğr. Üyesi, Adana Bilim ve Teknoloji Üniversitesi, İșletme Fakültesi Adana, Türkiye, E-posta: soguz@adanabtu.edu.tr ORCID ID https://orcid.org/0000-0002-1951-3821

*** Dr. Öğr. Üyesi, İstanbul Gelişim Üniversitesi, İ.İ.S.B.F., İstanbul, Türkiye,

E-posta: okizildemir@gmail.com ORCID ID https://orcid.org/0000-0002-0681-6137

**** Arş. Gör., Adana Bilim ve Teknoloji Üniversitesi, İşletme Fakültesi, Adana, Türkiye,

E-posta: neker@adanabtu.edu.tr ORCID ID https://orcid.org/0000-0002-2891-2592 


\title{
The Role of Tourism Sector in Regional Development in Adana
}

\begin{abstract}
Tourism has become one of the fastest growing and expanding industries in the world economy since the second half of the 20th century (C.imat ve Bahar, 2003; UNWTO, 2014). According to the United Nations World Tourism Organization (UNWTO) report published in 2013, it is understood that the number of people participating in international travel has exceeded 1 billion, and as a result of these movements an income of over 1 trillion dollars has been obtained (UNWTO, 2016). This research starts with examining the existing tourism potential of the Adana destination and examines the expenditures of tourists within the tourism destination. The role of these tourist expenditures in regional development was evaluated based on the economic effects of the destination. The purpose of this research is to evaluate the economic contribution of the tourism industry to the Adana economy in regional development. The increase in the number of tourists coming to Adana shows the necessity to measuring the contribution of tourism to the provincial economy. Within the scope of the study, a regional development survey was applied to 600 tourists visiting Adana province 396 of whom were Turkish Citizen. According to the results of the research, average tourist expenditure per person is $2232 \mathrm{TL}$. The result of multiplying the number of arriving tourists by the average per capita expenditure seems to have contributed directly to the Adana economy with approximately 2.44 billion TL / 642 million $\$(1 \$=3.8 \mathrm{TL})$. The development of tourism in Adana will provide economic contributions to the region and will contribute to the development of transport networks, infrastructure and superstructure, tourism enterprises, employment and other sectors in the region.
\end{abstract}

Keywords: Tourism Sector, Tourist Spending, Economic Impact Regional Development, Adana.

\section{Giriş}

Turizm günümüzde Türkiye dâhil olmak üzere birçok ekonomi açısından önemi giderek artan bir sektördür. Bu sektörün hangi nedenlerden dolayı önemli olduğu, tek başına bu sektöre dayalı ekonomik büyümenin mümkün olup olmayacağı, turizm talebi ve arzına ait özellikler ile ekonomiye mal ve hizmet sunan diğer sektörlerin özellikleri arasındaki benzerlik ve farklılıkların neler olduğu, turizmin doğal hammaddesi kabul edilen deniz, güneş, kum, tarih ve kültür değerlerinin üst yapı olmadan ne dereceye kadar çekim gücü yaratabilecekleri, var olan kaynakların kullanım sınırının bulunup bulunmadığl, küresel eğilimlerin etkisiyle uluslararası turizmin ne yönde șekil değiştirdiği, çok uluslu firmaların turizm piyasalarına etki derecelerinin hangi düzeyde olduğu, iç ve dış turizm harcamalarının ekonomide yarattığı gelir akımının etlilerinin neler olduğu gibi bir dizi sorular ve bu sorulara ait yanttlar turizm ekonomisinin ilgi alanına girmektedir (Yağcl, 2007:1).

Sanayi devrimiyle birlikte insanlar tarımdan ve doğadan uzaklaşmaya başlamıştır. Yaşadığı yerden uzaklaşmak için ise turistik faaliyetlere katılmaya başlayarak turizm sektörünün gelişmesini sağlamışlardır. Turizm talebinin 
artması ile turizm kaynakları olan destinasyonlarda turizmin ekonomik etkileri artırmıştır. Hatta bir çok destinasyon için turizm, en önemli gelir kaynağı ve ekonomik kalkınma aracı olmuştur. Diğer yandan sadece ekonomik katkısı ile değil, sosyo-kültürel etkileri, çevresel etkileri ve ülkenin tanıtımına olan etkileri nedeni ile de öncü sektör olarak kabul edilmeye başlamıştır. Turizmin artan önemi nedeniyle daha fazla pay almak isteyen hem az gelişmiş ülkeler, hem gelişmekte olan ülkeler, hem de gelişmiş ülkelerin turizm gelirlerini kendine çekmek için çok çeşitli ve yönlü stratejiler ortaya koymaktadırlar.

Birleşmiş Milletler Dünya Turizm Örgütü (UNWTO)'nün 2016 yılında yayınlanan raporuna göre ise uluslararası seyahatlere katılan kişi sayısının 1 milyarı geçtiği, bu hareketler sonucunda 1 trilyon doların üzerinde bir gelir elde edildiği anlaşılmaktadır (UNWTO, 2016). Türkiye'nin turizm rakamları Türkiye İstatistik Kurumu verilerine göre incelendiğinde ise 2016 yllında bir önceki yıla göre \% 30 azalarak 22.107.440 dolara gerilediği görülmektedir. Gelen turist sayısı bakımından 2015 yılında, 41.617 .530 kişi iken 2016 yılında bu rakam 31.365.330 olmuştur. Ortalama kişi başına harcama ise 2015 yılında 756 dolar iken, 2016 yılında bu rakam 705 dolara düşmüştür. Gayri Safi Milli Hâsıla (GSMH) içerisindeki payına bakıldığında, 1980 yılında 0,6 iken 2015 yılında 6,2 ve 2016 yılında ise bu rakam 2,6 rakamlarına ulaştığı görülmektedir. (TUIK, 2016). Turizm gelirlerinin Türkiye 2023 Stratejisine göre ise, 2023 yılında, 63 milyon turist, 86 milyar dolar diş turizm geliri ve turist başına yaklaşık 1350 dolar harcamaya ulaşılması öngörülmektedir. Bu bağlamda turizmin ekonomik etkilerinin hem küresel hem de Türkiye açısından ne kadar önemli bir yere sahip olduğu rakamlarla da görülmektedir (Türkiye Turizm Stratejiler 2023 Eylem Planı 2007-2013).

Konuya Adana ili açısından bakıldığında ise; Adana, ilk sanayileşen şehirlerden biri olmuştur. Pamuk, buğday, soya fasulyesi, arpa, üzüm ve narenciyenin büyük miktarlarda üretildiği Çukurova tarım bölgesinin pazarlama ve dağıtım merkezidir. Tekstil ve deri sanayi Adana'nın üretiminin \%29'unu oluşturan büyük sanayi kollarıdır ve bitkisel yağ ile işlenmiş yiyecek üreten tesisler de sayıca fazladır. Otomotiv sanayide Adana'nın en büyük firması olan Temsa'nın 2.500'den fazla çalışana sahip olup yıllık 4.000 otobüs üretmektedir. Güney Türkiye'deki önde gelen ticari merkezlerden biri olan şehir birçok şirketin ve kamu kuruluşunun bölgesel müdürlüklerine ev sahipliği yapmaktadır. Tarım ile birlikte hayvancılık da coğrafi koşulların imkân vermesiyle Adana ekonomisine ülke ekonomisinin ortalamasının üstünde katkı sağlamaktadır. Büyükbaş ve küçükbaş hayvancılığın yanı sıra, Akdeniz'e kıyısı bulunan Adana'nın ilçeleri Yumurtalık ve Karataş'ta deniz mahsulleri üretimi de önemli bir yer tutmaktadır (http://www.adana.bel.tr, Erişim Tarihi: 02.10.2017). Eski çağlardan beri askeri ve ticari yollar üstünde yer alan Adana, tarihin her döneminde çeşitli devreler için çekici bir yer olmuştur. Günümüzde 1 milyar 700 milyon doları aşan ihracatıyla Adana, ekonomi, ticaret, sanayi ve bankacılık alanlarında Türkiye'nin önde gelen şehirlerinden birisidir (http://www.adana.gov.tr, Erişim Tarihi 02.10.2017). Adana ili, Anadolu, Mezopotamya ve Doğu Akdeniz arasında köprü vazifesi görmesi, coğrafi 
konumu, kara, deniz ve ırmaklar üzerinden sağladığı ulaşım kolaylığı, dört mevsim hiç eksilmeyen güneşi ile tarih boyunca birçok medeniyete ev sahipliği yapmıştır. Binlerce yıllık tarihi geçmişi, bu geçmişten günümüze kalan sayısız tarihi eserleri; kaleleri, antik kentleri, konakları, mutfağı, doğal güzellikleri, el sanatları; coğrafi ve iklim özellikleri nedeniyle mevcut turizm potansiyeli ve çeşitliliği açısından oldukça zengin bir ildir (Adana İli Potansiyel Yatırım Konuları Araştırması, 2016: 147). Adana'da Adana İl Kültür Turizm Müdürlüğü 2016-2017 verilerine göre, turizm ve belediye belgeli toplam 10.772 yatak kapasitesi, 7 adet yiyecek içecek işletmesi, 129 adet seyahat acentesi, 143 adet rehber mevcuttur (Adana İl Kültür ve Turizm Müdürlüğü, Erişim Tarihi 02.10.2017). Belirtilen bu rakamlar ışığında turizmin çoğu zaman hesaplanamayan giderlerine rağmen hala dünyada pek çok ülke ekonomisi için çekiciliği sürmektedir.

$\mathrm{Bu}$ araştırmanın amacı; bölgesel kalkınmada Adana ekonomisine turizmin ekonomik katkılarını değerlendirmektir. Adana'ya gelen turist sayısının yıllar itibariyle artış göstermesi il ekonomisine turizmin katkısının ölçülmesi gerekliliğini ortaya koymaktadır. Ayrıca bu çalışmanın Adana gibi önemli turistik çekiciliklere sahip bir destinasyondaki yerel paydaşlara, yatırımcılara, ulusal ve bölgesel planlayıcılara ışık tutması açısından da önemli bir kaynak olacağı düşünülmektedir.

\section{Adana'da Turizm Sektörü}

Adana'nın mevcut turistik kaynakları bölgesel kalkınma açısından değerlendirildiğinde faydalı olabilecek düzeyde olduğu düşünülmektedir. Bu bağlamda Adana'nın turistik arz ve talebi konularının incelenmesi bölgesel kalkınmaya katkısının ölçülmesi açısından faydalı olacaktır.

\subsection{Adana'nın Turistik Arz ve Talebi}

Adana'nın Akdeniz'e bulunan 160 km sahili, 300 gün güneşli havası, yüzlerce tescilli kültür varlığı, binlerce arkeolojik ve etnoğrafik eseri, yüzlerce çeșit bitkisi, trekking (dağ yürüyüşü) alanları, yaylaları ve doğal güzellikleri ile turizmin her çeşidine olanak sağlayarak Adana'nın kalkınması açısından önemli turistik kaynaklara sahip olduğu görülmektedir (Adana Turizm Master Planı, 2016: 42).

Turizm arzı olarak Adana'da bulunan konaklama işletmeleri (belediye belgeli ve turizm belgeli), seyahat işletmeleri ve turizm belgeli yeme-içme (lokantalar) tesislerinin rakamları aşağıdaki tablo 1 , tablo 2 ve tablo 3 'te özetlenmektedir.

\begin{tabular}{|l|l|l|}
\hline \multicolumn{3}{|c|}{ Tablo 1. Adana Turizm Belgeli Tesis ve Yatak SayıSı (2016) } \\
\hline SINIFI & SAYISI & YATAK SAYISI \\
\hline 5 yıldızlı Otel & 6 & 2.350 \\
\hline 4 ylddızlı Otel & 16 & 2.557 \\
\hline 3 yıldızlı Otel & 14 & 1.559 \\
\hline
\end{tabular}




\begin{tabular}{|l|l|l|}
\hline \multicolumn{2}{|l|}{ Tablo 1. Adana Turizm Belgeli Tesis ve Yatak Sayısı (2016) } \\
\hline 2 yıldızlı Otel & 4 & 331 \\
\hline Motel & 4 & 250 \\
\hline Butik Otel & 1 & 60 \\
\hline Müstakil Otel & 1 & 56 \\
\hline Özel Belgeli Otel & 2 & 92 \\
\hline TOPLAM & $\mathbf{4 8}$ & $\mathbf{7 . 2 5 5}$ \\
\hline
\end{tabular}

Kaynak: Adana İl Kültür ve Turizm Müdürlüğü, 2016.

Tablo 1'de görüldügü üzere Adana'da turizm belgeli otel sayısının 48 yatak sayısının ise 7.255 olduğu anlaşılmaktadır. Tablo 2'ye göre Adana'da belediye belgeli konaklama işletmelerinin toplam tesis sayısının 75, yatak sayısının ise 3.517 olduğu görülmektedir. Bu bağlamda Tablo 1 ve Tablo 2 'den anlaşılacağl üzere Adana'da turizm belgeli ve belediye belgeli konaklama işletmelerinde toplam yatak sayısı 10.772'dir.

Tablo 2. Adana'nın İlçelere Göre Belediye Belgeli Konaklama Tesis, Oda ve Yatak Sayıları

\begin{tabular}{|l|l|l|l|}
\hline \multicolumn{1}{|c|}{ İLÇE } & \multicolumn{1}{c|}{ TESIS SAYISI } & \multicolumn{1}{c|}{ ODA SAYISI } & \multicolumn{1}{c|}{ YATAK SAYISI } \\
\hline ALADAĞ & 2 & 28 & 64 \\
\hline CEYHAN & 4 & 99 & 188 \\
\hline ÇUKUROVA & 0 & 0 & 0 \\
\hline FEKE & 0 & 0 & 0 \\
\hline İMAMOĞLU & 0 & 0 & 0 \\
\hline KARAİSALI & 0 & 0 & 0 \\
\hline KARATAŞ & 12 & 216 & 422 \\
\hline KOZAN & 1 & 12 & 13 \\
\hline SAİMBEYLİ & 2 & 20 & 40 \\
\hline SARIÇAM & 0 & 0 & 0 \\
\hline SEYHAN & 29 & 777 & 1.321 \\
\hline TUFANBEYLI & 2 & 46 & 86 \\
\hline YUMURTALIK & 19 & 377 & 1.149 \\
\hline POZANTI & 3 & 40 & 74 \\
\hline YÜREĞİ & 1 & 83 & 160 \\
\hline TOPLAM & $\mathbf{7 5}$ & $\mathbf{1 . 6 9 8}$ & $\mathbf{3 . 5 1 7}$ \\
\hline
\end{tabular}

Kaynak: Adana İl Kültür ve Turizm Müdürlüğü, 2016.

Adana'da bulunan bir diğer turizm işletme çeşidi olan seyahat acentelerinin toplam sayısının 129 adet olduğu Tablo 3'ten anlaşılmaktadır. Tablo 3'e göre Adana'da faaliyet gösteren seyahat acentelerinin çoğunluğunu A grubu oluşturduğu görülmektedir. 


\begin{tabular}{|c|c|}
\hline \multicolumn{2}{|c|}{ Tablo 3. Adana Seyahat Acentleri Sayıları } \\
\hline Acenta Grubu & Sayısı \\
\hline $\begin{array}{c}\text { A Grubu Seyahat } \\
\text { Acentaları(MERKEZ) }\end{array}$ & 83 \\
\hline $\begin{array}{c}\text { A Grubu Seyahat } \\
\text { Acentaları(ŞUBE) }\end{array}$ & 39 \\
\hline C Grubu Seyahat Acentaları & 7 \\
\hline TOPLAM & $\mathbf{1 2 9}$ \\
\hline
\end{tabular}

Kaynak: Adana İl Kültür ve Turizm Müdürlüğ̈̈, 2016.

Adana İl Kültür ve Turizm Müdürlüğü (2016) verilerine göre ise turizm belgeli yeme-İçme tesis sayısının ise sadece 7 adet olduğu anlaşılmaktadır. Bu sayının az olması Adana'da faaliyet gösteren yeme-içme tesislerinin büyük çoğunluğunun belediye belgeli olarak faaliyet göstermesidir.

Adana'da turizm ișletmesi olarak faaliyet gösteren turistik arzların bir diğer boyutu ise şehirdeki turizm kaynaklarıdır. Bu bağlamda Adana'nın sahip olduğu turizm kaynakları ise genel olarak müzeler, geleneksel evler, antik kentler, kaleler, kiliseler, köprüler, kervansaraylar, hanlar, camiler, konaklar, saat kulesi, anıtlar, şelaleler, milli parklar, tabiat parkları, baraj gölü, çeşitli festivaller ve kendine özgü mutfağı olarak sıralayabilmek mümkündür. Yukarıda sayılan turizm kaynakları Adana'ya turizm talebi oluşturmada kolaylık sağlayabilecek en temel faktörlerdir.

Adana'nın sahip olduğu turistik arzlar çeşitli turizm türlerinin yapılmasına olanak sağlamaktadır. Bu bağlamda Adana'nın sahip olduğu turizm kaynaklarına olan turistik talebin artışının sağlanması ile birlikte bölgesel kalkınma açısından faydalı olabileceğini söylemek mümkündür. Adana'nın mevcut turizm talebi Tablo 4'te incelenmektedir. Tablo 4'e göre belediye belgeli konaklama işletmelerinde en fazla konaklamanın 2014 yılında olduğu görülmektedir. 2015 yılında ise konaklama sayısının neredeyse yarı yarıya düştüğü anlaşılmaktadır.

\begin{tabular}{|l|l|l|l|}
\hline \multicolumn{4}{|l|}{ Tablo 4. Belediye Belgeli Konaklama Tesislerindeki Toplam Turist Sayıları } \\
\hline \multirow{4}{*}{ YILLAR } & \multicolumn{3}{|l|}{ Belediye Belgeli İşletmeler } \\
\cline { 2 - 4 } & $\begin{array}{l}\text { Tesise geliş sayısı } \\
\text { / Vatandaş }\end{array}$ & $\begin{array}{l}\text { Tesise geliş } \\
\text { sayısı / Yabancı }\end{array}$ & $\begin{array}{l}\text { Tesise geliş sayısı / } \\
\text { Toplam }\end{array}$ \\
\hline 2011 & 54.836 & 452 & 55.288 \\
\hline 2012 & 127.359 & 2.540 & 129.899 \\
\hline 2013 & 202.563 & 12.966 & 215.529 \\
\hline 2014 & 340.621 & 9.527 & 350.148 \\
\hline 2015 & 168.601 & 16.151 & 184.752 \\
\hline
\end{tabular}

Kaynak: Kültür ve Turizm Bakanlı̆̆ı, 2016.

Tablo 5 Adana'da turizm işletme belgeli konaklama tesislerindeki konaklama yapan yerli ve yabancı turist sayılarını göstermektedir. Buna göre en fazla konaklamanın 2015 yılında yapıldığı ve genel olarak 2011 yılından 
itibaren konaklama yapan turistlerin sayılarında bir artış eğilimi olduğu yorumunu yapmak mümkündür.

\begin{tabular}{|c|c|c|c|}
\hline \multicolumn{4}{|c|}{$\begin{array}{l}\text { Tablo 5. Turizm İşletme Belgeli Konaklama Tesislerindeki Toplam Turist } \\
\text { Sayıları }\end{array}$} \\
\hline YILLAR & \multicolumn{3}{|c|}{ Turizm İșletme Belgeli İșletmeler } \\
\hline & $\begin{array}{l}\text { Tesise geliş sayısı / } \\
\text { Vatandaș }\end{array}$ & $\begin{array}{c}\text { Tesise geliş sayısı / } \\
\text { Yabancı }\end{array}$ & $\begin{array}{c}\text { Tesise geliş } \\
\text { sayısı / Toplam }\end{array}$ \\
\hline 2011 & 282.584 & 40.220 & 322.804 \\
\hline 2012 & 284.583 & 39.592 & 324.175 \\
\hline 2013 & 371.153 & 44.641 & 415.794 \\
\hline 2014 & 406.224 & 51.782 & 458.006 \\
\hline 2015 & 487.674 & 52.632 & 540.306 \\
\hline
\end{tabular}

Kaynak: Kültür ve Turizm Bakanlı̆̆ı, 2016.

Sonuç olarak Adana'da 2015 yılı itibari ile belediye belgeli ve turizm belgeli konaklama işletmelerinde konaklama yapan yerli ve yabancı turistlerin sayılarına bakıldığında toplamda 725.058 olduğu anlaşılmaktadır.

\section{Bölgesel Kalkınma}

Bölgesel kalkınma, bölgenin sahip olduğu kaynaklarının harekete geçirilmesi ve girişimciliğin özendirilmesi ile birlikte bölgedeki gelir seviyesinin ve istihdamının arttırılması, yaşam standartlarının iyi bir seviyeye gelmesi olarak tanımlanabilir (Durgun, 2006: 42). Bir başka değişle ise şehir, metropoliten alan ve alt ulusal bölge olarak tanımlanan topluluktaki herkesin yaşam kalitesini artıran ve ekonomik faydaları yükselten sürdürülebilir ekonomik büyümeyi gerçekleştirmek için yerel otoritelerin, özel sektörün, kar amacı olmayan kurumların ve yerel halkın birlikte çalışması şeklinde tanımlanmaktadır (Kaypak, 2013: 203).

Bölgesel kalkınma ve turizm ilişkisi incelendiğinde turizm sektörünün az gelişmiş ve geri kalmış bölgelerin gelişmesine, ekonominin yeniden yapılandırılmasına ve sonuçta bir bütün olarak ekonomik büyüme ile kalkınmaya bir araç olarak kullanılmaktadır (Bahar, 2007). Turizmin bölgesel kalkınmaya etkisi yukarıda ifade edilen özelliklerin dışında şu şekilde sıralamak mümkündür (Çeken, 2008:300-302);

- Turizm sayesinde ihracı mümkün olmayan, jeo-ekonomik varlıklar, sosyo-kültürel varlık, değer ve olaylar ile spesifik bazı hizmetler bölge için döviz kaynağı haline gelmektedir.

- Bölgeye gelen yerli ve yabancı turistlerin yapmış oldukları turistik tüketim harcamaları ile artan turizm talebini karşılamak amacıyla yapılan turistik yatırımlar gerek turizm sektöründe gerekse sektörü belirleyen diğer sektörlerdeki üretim faktörlerinin gelirlerini arttırır.

- Turizm sektörü her ne kadar hizmet sektörü içinde yer alsa da taşıdığı özellikler nedeniyle 37 tane sektörle yakın bir ilişki içindedir. Yani bir ülkede veya bölgede turizmin gelişmesi aynı zamanda 37 tane sektörün 
de gelişmesi demektir. Ancak turizmin sektörler üzerindeki o ülkede veya bölgede gelişmiş olan turizm çeşidine göre farklılıklar arz etmektedir.

- Turizm sektörüne paralel olarak turizmin gelir etkisinin artması, tarım sektöründe üretim kalitesinin artmasına, standardizasyonun sağlanmasına ve kaliteli ürünün gerçek değerini bulmasına neden olur. Bunun sonucunda o bölgede tarımla geçinen kesimin gelirinde bir artış olacaktır. Turizm olmasaydı bu ürünler gerçek değerini bulamayacak ve halkın gelirinde düşüş olacaktı. Bu durum özellikle Türkiye için son derece önemlidir. Çünkü halkın büyük bir bölümü tarımla geçinmektedir. Tarım ekonomisinin yaygın olduğu bölgelerde turizmin gelişmesi demek tarımla geçinen halkın gelir ve refah seviyesinin artması demektir. Tarım sektöründeki gizli ișsizlik sorunu da turizmin gelișmesine paralel olarak ortadan kalkmaktadır. Dolayısıyla işsiz kesimin sanayileşmiş bölgelere göç etmesinin önüne geçilmekte ve bölgelerarası dengesizlik de en aza indirilmiş olmaktadır.

- Turizm sektörünün gelişmesi sonucunda, bölgede ikamet edenler, evlerini pansiyon olarak turistlere kiraya verme yoluyla bir gelir elde etmektedirler. Bununla birlikte, aile ve turistlerin aynı çatı altında birlikte yaşamaları sosyo-ekonomik kalkınmaya olumlu yönden katkı sağlamaktadır. Turizm yoluyla kısa sürede oluşan sosyo-ekonomik içerikli yapı değişimi, çağdaş uygarlık düzeyine ulaşma savaşı veren toplumlar için son derece önemlidir.

- Turizmin geliştiği bölgelerde aynı zamanda bölgede bir çevre bilincinin gelişmesine de yol açmaktadır. Temiz bir çevre turizmin temel sermayesidir. Turizm çevreyi koruyacak, hava ve su kirlenmesini önleyecektir. Yörede sürdürülebilir bir çevre modeli gelişecek ve kalkınma sürecinin gelişmesine neden olacaktır.

- Turizmin gelişmesi sonucunda bölgede, kalkınma hızı ile nüfus artış hızı arasındaki dengesizliğin sebep olduğu iç göçler, turizm nedeniyle yer yer azalacak veya duracaktır. Bu süreç kentlerin gecekondulaşmasını veya çarpık kentleşme hızını yavaşlatacaktır. Turizmin, çözümü güç ve aşılması zor olan bu toplumsal sorunların çıkmasını önleyici ve azaltıcı bu fonksiyonu, ülkenin kalkınmasına bir katkı olarak değerlendirilmektedir.

- Turizm arz potansiyeline sahip çekim bölgelerde oturanların sahip oldukları sosyo-kültürel değerleri yıpranmayacak hatta değer kazanacaktır. Çünkü yörenin sahip olduğu gelenekler ve görenekler bölge için birer çekim unsuru olacaktır. Bu çekim unsurlarının zenginliği aynı zamanda bölgenin de gelişim sürecini hızlandıracaktır.

\section{Metodoloji}

Turizmin toplumlar üzerinde ekonomik, kültürel, sosyal, çevresel etkileri olduğu bilinmektedir. Turizmin bu etkilerinin destinasyon bazında tespit 
edilmesi ve bilgilerin paydaşlara sunulması, söz konusu destinasyonda turizmi daha ileri noktalara taşımak ve kalkınmasına destek olmak adına önem arz etmektedir. Turizmin bölgesel kalkınma üzerindeki etkileri onu kritik bir noktaya taşımaktadır.

Ulusal ve uluslararası arenada turizmin bölgesel kalkınmaya etkilerini konu alan pek çok çalışma mevcuttur. Turizmin gelişmiş olduğu destinasyonlarda turizmin bölgesel kalkınma ile ilişki açık bir şekilde ortaya konmaktadır. Bu çalışmada bölge ekonomisi turizme bağlı olmayan bir şehir olarak Adana ili ele alınmaktadır. Tarihi değerleri, doğal çekicilikleri, yerel kültürü, gastronomisi, fuar ve festivalleri ile dikkat çekmesine rağmen turizmde henüz hak ettiği yere kavuşamamıștır. Yapılan bu çalışma ile Adana ilinde turizmin bölgesel kalkınmaya etkilerinin belirlenmesi amaçlanmakta olup, ayrıca Kızıldemir'in 2015 yılındaki topladığı veriler ile kıyaslama yaparak bölgede turizmin gelişmesi adına önemli bulgular ortaya koyması ve bir öneri niteliği taşıması planlanmaktadır.

Adana'nın bölgesel kalkınmasında turizmin rolünü ölçmeyi hedefleyen bu çalışmada nicel araştırma yöntemlerinden biri olan anket tekniği kullanılmıştır. Çalışmada kullanılan anket formu iki bölümden oluşmaktadır. Anketin birinci bölümü katılımcıların demografik bilgilerine ilişkin veri elde edilmesi amacıyla oluşturulan demografik sorular ile seyahat süreçlerine ilişkin sorulardan oluşmaktadır. Uygulanan ölçeğin ikinci kısmı katılımcıların Adana'da kaldıkları süreçte yapmış oldukları harcamaları tespit etmek amaçlı soruları içermektedir. Bu çalışmada Kızıldemir'in (2017) doktora tezinde kullanmış olduğu ölçek temel alınmıştır.

Araştırma evreni Adana ilinde ziyaret eden yerli ve yabancı turistler olup bu rakam 2017 yılı için 1.094.335 kişidir (www.adanakulturturizm.gov.tr ). Hazırlanan ölçek, evreni temsil edeceği düşünülerek (Yazıcıoğlu ve Erdoğan, 2014) 600 katılımcıya uygulanmıștır. Bu çalışmada olasılığa dayalı olmayan örnekleme yöntemlerinden kasti örnekleme metodu kullanılmıştır. Bu araştırmada Adana ilini ziyaret eden yerli ve yabancı turistlerin tatil süreçlerinde yaptıkları harcamaların tespit edilmesi amaçlandığı için, Adana'dan ayrılmak üzere olan ziyaretçileri tespit etmek üzere Adana Şakir Paşa Hava Limanı'nda giden yolcu peronlarında katılımcılara anket uygulanmıştır. Veri toplama işlemi 25 Aralık 2017- 5 Ocak 2018 tarihi arasında gerçekleştirilmiştir.

\subsection{Bulgular}

\subsubsection{Katılımcıların Demografik Değişkenleri ve Tatil Süreçlerine İlişkin Bulgular}

Araştırmaya dâhil edilen katılımcıların milliyetleri ve yaşadıkları ülkeler hakkındaki bilgiler çapraz tablo ile analiz edilerek Tablo 6'da verilmiştir. 


\begin{tabular}{|c|c|c|c|c|c|c|c|c|c|c|c|c|c|c|}
\hline & \multicolumn{14}{|c|}{ YAȘANILAN ÜLKE } \\
\hline MILLIYET & بّ̂ & 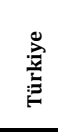 & $\stackrel{\Xi}{\Xi}$ & 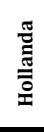 & $\begin{array}{l}\mathbb{W} \\
\text { E్ } \\
\text { E్ }\end{array}$ & 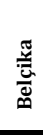 & 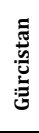 & 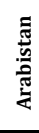 & 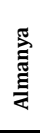 & $\stackrel{\bar{n}}{\sum}$ & 忥 & 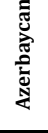 & 离 & 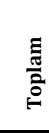 \\
\hline TC Vatandașı & 110 & 105 & 1 & 29 & 29 & 26 & 15 & 16 & 20 & 18 & 4 & 4 & 19 & 396 \\
\hline KKTC Vatandaşı & 56 & - & - & - & - & - & - & - & - & - & - & - & - & 56 \\
\hline $\begin{array}{l}\text { Suriye } \\
\text { Vatandașı }\end{array}$ & - & 2 & 45 & - & - & - & - & - & - & - & - & - & - & 47 \\
\hline $\begin{array}{l}\text { Arabistan } \\
\text { Vatandașı }\end{array}$ & - & - & 1 & - & - & - & - & 10 & - & - & 6 & - & - & 17 \\
\hline $\begin{array}{l}\text { Gürcistan } \\
\text { Vatandașı }\end{array}$ & 2 & - & - & - & - & - & 11 & - & - & - & - & - & - & 13 \\
\hline $\begin{array}{l}\text { Azerbaycan } \\
\text { Vatandașı }\end{array}$ & - & - & - & - & - & - & - & - & - & - & - & 9 & - & 9 \\
\hline $\begin{array}{l}\text { Türkmenistan } \\
\text { Vatandaşı }\end{array}$ & 2 & - & - & - & - & - & - & - & - & - & - & - & 7 & 9 \\
\hline $\begin{array}{l}\text { Hollanda } \\
\text { Vatandași }\end{array}$ & - & - & - & 8 & - & - & - & - & - & - & - & - & - & 8 \\
\hline $\begin{array}{l}\text { Diğer Ülke } \\
\text { Vatandașları2 }\end{array}$ & - & - & - & 1 & 1 & 3 & - & - & 1 & 3 & 6 & - & 30 & 45 \\
\hline Toplam & 170 & 107 & 47 & 38 & 30 & 29 & 26 & 26 & 21 & 21 & 16 & 13 & 56 & 600 \\
\hline
\end{tabular}

Tablo 6, katılımcıların milliyetlerine ve yaşadıkları ülkelere ilişkin bilgileri içermektedir. Çapraz tablo incelendiğinde 396 katılımcının TC vatandaşı olması; 170 katılımcının KKTC’nde, 107 katılımcının Türkiye'de ikamet ediyor olması; Belçika, Hollanda, Fransa ve Almanya vatandaşlarının milliyet bazında en çok katılıma sahip olan ülkeler olduğu dikkat çekmektedir. Araștırmaya dâhil olan 600 katılımcının 107'si Türkiye'de ikamet ederken, 493 katılımcının ülke dışında ikamet ettiği anlaşılmaktadır.

Araştırmaya dâhil olan katılımcılara ait demografik bilgiler Tablo 7'de gösterilmektedir.

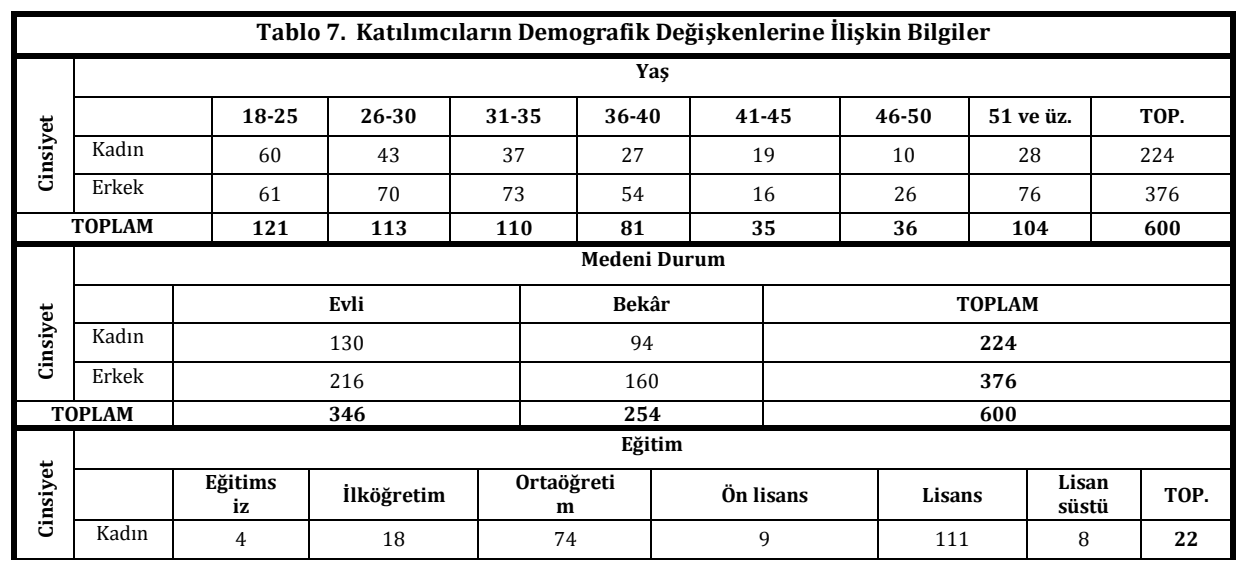

\footnotetext{
${ }^{1}$ Katar, Belçika, Mısır, Ukrayna, Rusya, Lübnan, Irak, Sırbistan, Ermenistan, Bulgaristan, Fransa, Almanya

2 Lübnan, Irak, Sirbistan, Ermenistan, Bulgaristan, Türkmenistan, Kırgızistan, Japonya, İngiltere, Fas, Tayland, Avustralya
} 


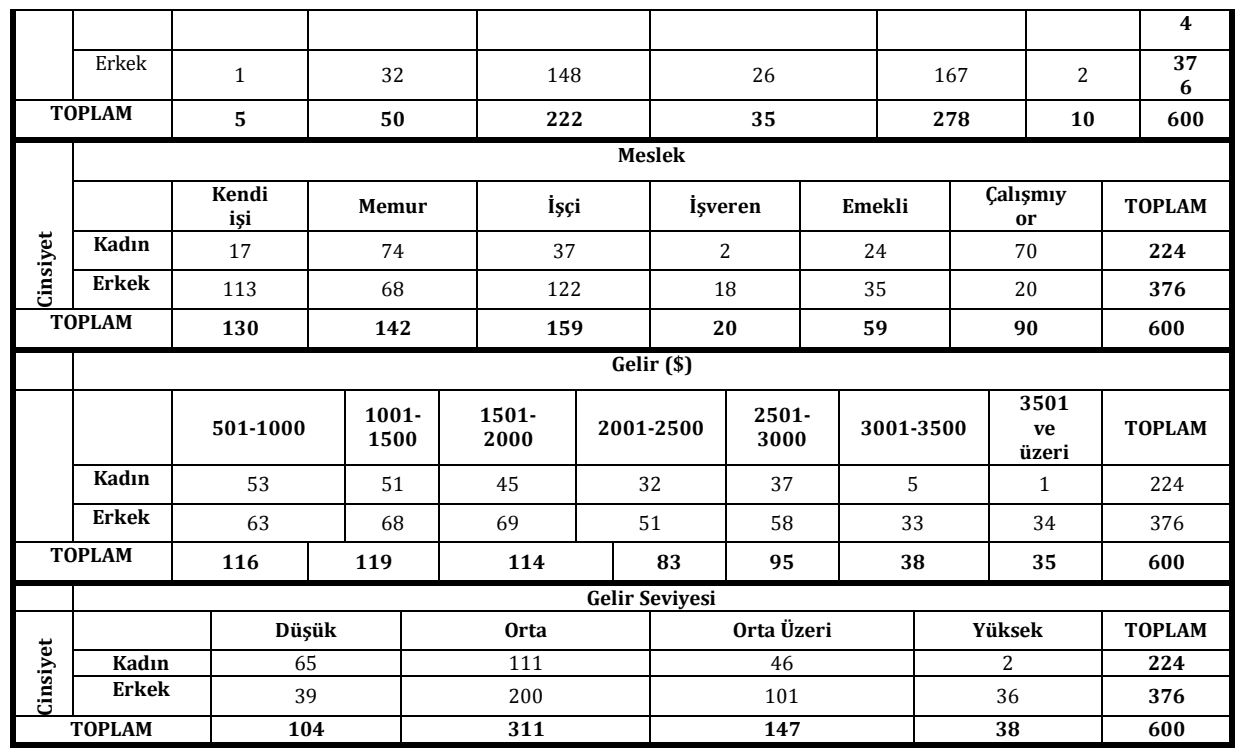

Tablo 7'de yer alan demografik bilgilere göre katılımclların 224'ünün kadınlardan ve 376'sının erkek katılımcılardan oluşmaktadır. Katılımcıların çoğu 18-25 yaş grubu arasında yer almaktadır. Cinsiyet farklılığı ile yaşlara bakıldığında kadınların çoğunun 18-25, erkeklerin çoğunun 51 yaş üzeri grupta yer aldığı görülmektedir. Hem kadın hem de erkek katılımcıların çoğu evlidir. Eğitim durumlarına bakıldığında eğitimsiz olanlar ile lisansüstü düzeyde eğitime sahip olanların azınlıkta olduğu dikkat çekmektedir. Eğitim düzeyinde katılım, hem erkeklerde hem de kadınlarda lisans düzeyinde çoğunluk göstermektedir. Katılımcılar arasında kadınların çoğu çalışmamaktadır, çalışan kadınların ise çoğu memurdur. Erkek katılımcılarda ise işçi ve kendi işi yapan katılımcıların çoğunlukta olduğu tabloda gösterilmektedir.

Katılımcıların gelir düzeyleri incelendiğinde kadın katılımcılarda 3500 \$ üzeri gelire sahip sadece 1 katılımcı var iken, kadınlarının çoğunun 500-1000\$ arası gelir elde ettiği gözlemlenmektedir. Erkek katılımcılarda çoğunluğun 1501-2000\$ gelire sahip olduğu; bunu takiben en fazla katılımın 3001'doların üzerinde olduğu tablodan açıkça anlaşılmaktadır. Bununla birlikte hem kadın hem de erkek katılımcılar kendilerinin orta düzey gelir seviyesinde olduklarını ifade etmişlerdir. Elde edilen gelir ile gelir seviyesi kendi içinde çapraz tablo analizine tabi tutulmuş olup tablo 9'da gösterilmektedir. Eğitim seviyesi ve meslek grupları kendi içinde çapraz tablo analizine tabi tutulmuş olup Tablo 8'de gösterilmektedir. 


\begin{tabular}{|c|c|c|c|c|c|c|c|c|}
\hline \multirow{2}{*}{\multicolumn{2}{|c|}{ Tablo 8. Katılımcıları }} & \multicolumn{6}{|c|}{ Meslek } & \multirow[b]{2}{*}{ Toplam } \\
\hline & & 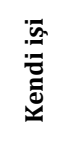 & $\begin{array}{l}\grave{\Xi} \\
\sum \\
\sum\end{array}$ & w & 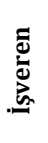 & $\begin{array}{l}\text { 咅 } \\
\text { : }\end{array}$ & 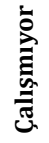 & \\
\hline \multirow{6}{*}{ 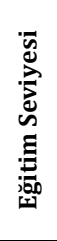 } & Eğitimsiz & 0 & 0 & 3 & 0 & 0 & 2 & 5 \\
\hline & İlköğretim & 6 & 0 & 29 & 0 & 6 & 9 & 50 \\
\hline & Ortaöğretim & 35 & 18 & 73 & 12 & 41 & 43 & 222 \\
\hline & Ön lisans & 8 & 13 & 7 & 1 & 3 & 3 & 35 \\
\hline & Lisans & 80 & 104 & 47 & 7 & 9 & 31 & 278 \\
\hline & Lisansüstü & 1 & 7 & 0 & 0 & 0 & 2 & 10 \\
\hline & Toplam & 130 & 142 & 159 & 20 & 59 & 90 & 600 \\
\hline
\end{tabular}

Tablo 8 incelendiğinde ilköğretim ve ortaöğretim düzeyinde eğitime sahip olan katılımcılarının çoğunun işçi olarak; ön lisans, lisans ve lisansüstü düzeyde eğitime sahip olanların memur olarak çalıştıkları dikkat çekmektedir.

Elde edilen gelir ile gelir seviyesi kendi içinde çapraz tablo analizine tabi tutulmuş olup tablo 9'da gösterilmektedir.

\begin{tabular}{|c|c|c|c|c|c|c|}
\hline & & \multicolumn{4}{|c|}{ Gelir Seviyesi } & \multirow[t]{2}{*}{ Toplam } \\
\hline & & Düșük & Orta & Orta Üzeri & Yüksek & \\
\hline \multirow{8}{*}{ 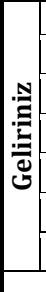 } & $501-1000$ & 46 & 70 & 0 & 0 & 116 \\
\hline & $1001-1500$ & 41 & 78 & 0 & 0 & 119 \\
\hline & $1501-2000$ & 17 & 90 & 7 & 0 & 114 \\
\hline & $2001-2500$ & 0 & 73 & 9 & 1 & 83 \\
\hline & 2501-3000 & 0 & 0 & 93 & 2 & 95 \\
\hline & $3001-3500$ & 0 & 0 & 38 & 0 & 38 \\
\hline & 3500 ve üzeri & 0 & 0 & 0 & 35 & 35 \\
\hline & Toplam & 104 & 311 & 147 & 38 & 600 \\
\hline
\end{tabular}

Tablo 10'a göre katılımcıların \%44,8'i akraba veya arkadaşlarını ziyaret etmek üzere; \%30,5'i tatil amaçlı Adana'ya gelmiştir. En az katılım ise ticari ve kültürel nedenlerdir. Tabloda yer alan bilgilere göre katılımcıların büyük çoğunluğu seyahatlerini bireysel olarak planlamışlardır. Bununla birlikte katılımcıların seyahatlerine ilişkin bilgi edindikleri en önemli bilgi kaynağı yine seyahat acentelerindir. Katılımcıların yarısının seyahatlerinin Adana dışındaki illeri de kapsadığı tabloda açıkça görülmektedir. 
Tablo 10. Katılımcıların Seyahatleri ve Seyahat Süreçlerine İlișkin Bilgiler Bu seyahatimizde Adana'yı seçmenizdeki en önemli amaç nedir?

\begin{tabular}{|c|c|c|}
\hline Bu seyahatimizde Adana' yı seçmenizdeki en onemli amaç nedir? & $\mathbf{N}$ & $\mathbf{P}$ \\
\hline Akraba-arkadaş ziyareti & 269 & 44,8 \\
\hline Tatil & 183 & 30,5 \\
\hline İş ilişkileri & 77 & 12,8 \\
\hline Toplantı konferans & 29 & 4,8 \\
\hline Eğitim- öğrenim & 10 & 1,7 \\
\hline Kamu hizmeti & 10 & 1,7 \\
\hline Sağlık Tedavisi & 9 & 1,5 \\
\hline Transit & 6 & 1,0 \\
\hline Kültürel & 4 & 0,7 \\
\hline Ticari & 3 & 0,5 \\
\hline Seyahatinizi nasıl organize ettiniz? & $\mathbf{N}$ & $\mathbf{P}$ \\
\hline Bireysel & 584 & 97,3 \\
\hline Seyahat Acentesi & 16 & 2,7 \\
\hline Seyahatiniz için gerekli bilgiyi sağladığınız en önemli kaynak hangisidir? & $\mathbf{N}$ & $\mathbf{P}$ \\
\hline Seyahat acentesi & 365 & 60,8 \\
\hline Eş, Dost ve Akraba & 126 & 21,0 \\
\hline İnternet & 54 & 9,0 \\
\hline Turizm Bürosu & 49 & 8,2 \\
\hline m TV, gazete, dergi vb. & 6 & 1,0 \\
\hline Bu seyahatiniz Adana dıșındaki şehirleri de kapsıyor mu? & $\mathbf{N}$ & $\mathbf{P}$ \\
\hline Hayır & 303 & 50,5 \\
\hline Evet & 297 & 49,5 \\
\hline
\end{tabular}

Tablo 11. Katılımcıların Konaklamalarına İlişkin Bilgiler

\begin{tabular}{|c|c|c|c|c|c|c|c|}
\hline \multicolumn{2}{|c|}{ Tatil süresi (Gün) } & \multirow{2}{*}{$\frac{\mathbf{N}}{32}$} & \multirow{2}{*}{$\frac{\mathbf{P}}{5,3}$} & \multirow{2}{*}{ Mean } & \multicolumn{3}{|c|}{ Otel Geceleme Sayısı } \\
\hline \multirow{22}{*}{ 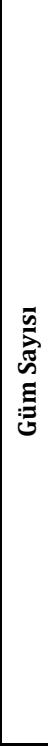 } & 1 Gün & & & & Geceleme & $\mathbf{N}$ & $\mathbf{P}$ \\
\hline & 2 Gün & 38 & 6,3 & \multirow{21}{*}{$\underset{m}{m}$} & 1 Gece & 24 & 4,0 \\
\hline & 3 Gün & 74 & 12,3 & & 2 Gece & 24 & 4,0 \\
\hline & 4 Gün & 52 & 8,7 & & 3 Gece & 35 & 5,8 \\
\hline & 5 Gün & 96 & 16,0 & & 4 Gece & 16 & 2,7 \\
\hline & 6 Gün & 45 & 7,5 & & 5 Gece & 57 & 9,5 \\
\hline & 7 Gün & 66 & 11,0 & & 6 Gece & 11 & 1,8 \\
\hline & 8 Gün & 19 & 3,2 & & 7 Gece & 12 & 2,0 \\
\hline & 9 Gün & 7 & 1,2 & & 8 Gece & 5 & 0,8 \\
\hline & 10 Gün & 67 & 11,2 & & 10 Gece & 2 & 0,3 \\
\hline & 11 Gün & 2 & 0,3 & & Toplam & 186 & 31 \\
\hline & 12 Gün & 8 & 1,3 & & Mean & & \\
\hline & 13 Gün & 4 & 0,7 & & Pansiyon & Ev G & Sayısı \\
\hline & 14 Gün & 6 & 1,0 & & Geceleme & $\mathbf{N}$ & $\mathbf{P}$ \\
\hline & 15 Gün & 45 & 7,5 & & 2 Gece & 2 & 0,3 \\
\hline & 17 Gün & 1 & 0,2 & & 6 Gece & 3 & 0,5 \\
\hline & 18 Gün & 3 & 0,5 & & 10 Gece & 1 & 0,2 \\
\hline & 19 Gün & 3 & 0,5 & & 12 Gece & 1 & 0,2 \\
\hline & 20 Gün & 16 & 2,7 & & 15 Gece & 1 & 0,2 \\
\hline & 21 Gün & 1 & 0,2 & & 20 Gece & 3 & 0,5 \\
\hline & 25 Gün & 2 & 0,3 & & 27 Gece & 1 & 0,2 \\
\hline & 27 Gün & 1 & 0,2 & & 28 Gece & 1 & 0,2 \\
\hline
\end{tabular}




\begin{tabular}{|c|c|c|c|c|c|}
\hline 28 Gün & 1 & 0,2 & 29 Gece & 2 & 0,3 \\
\hline 29 Gün & 2 & 0,3 & 30 Gece & 3 & 0,5 \\
\hline 30 Gün & 9 & 1,5 & Toplam & 18 & 3,0 \\
\hline Toplam & 600 & 100 & Mean & \multicolumn{2}{|c|}{17,8889} \\
\hline Kalınan yer & $\mathbf{N}$ & $\mathbf{P}$ & \multirow{2}{*}{\multicolumn{3}{|c|}{$\begin{array}{c}\text { Aile, Akraba Arkadaş Evi Geceleme Sayısı } \\
\text { Mean: } 8,5601\end{array}$}} \\
\hline Akraba Evi & 283 & 47,1 & & & \\
\hline Otel & 186 & 31,0 & & & \\
\hline Arkadaş Evi & 55 & 9,2 & & & \\
\hline Aile Evi & 52 & 8,7 & & & \\
\hline Pansiyon/Kiralık Ev & 18 & 3,0 & & & \\
\hline Hastane & 6 & 1,0 & & & \\
\hline
\end{tabular}

Katılımcıların tatil süreleri, konaklama yaptıkları yerler ve konaklama sürelerine ilişkin bilgiler tablo 11'de yer almaktadır.

Tablo 11 incelendiğinde, katılımcıların tatil sürelerinin bir günden bir aya kadar değişiklik gösterdiği dikkat çekmektedir. Tabloda yer alan bilgilere göre kişi başı ortalama tatil süresi yaklaşık bir haftadır (mean: 7,4433). Katılımcıların \%34'ü konaklamak için çeşitli büyüklükteki otelleri, pansiyonları ve kiralık evleri tercih ederken; \%65'i aile, akraba veya arkadaşlarının evlerinde konaklama yapmışlardır. Çeşitli büyüklükteki otellerde konaklama yapan 186 katılımcının oteldeki kişi başı ortalama gecelemesi yaklaşık 4 gecedir. Pansiyon ve kiralık evlerde ise kişi başı ortalama geceleme sayısı yaklaşık 18'dir. Aile, akraba ve arkadaş yanında tatillerini geçiren katılımcıların ortalama geceleme süresi ise $8,5^{\prime}$ tir.

\subsubsection{Katılımcıların Adana İlinde Yaptıkları Harcamalara İliş̧in Bulgular}

Adana'ya gelen turistlerin genel harcamalarını ve harcama kalemlerini gözlemleyebilmek için elde edilen verilere ilişkin bulgular bu bölümde ele alınmaktadır. Euro ve Dolar bazında yapılan harcamalar 25 Aralık 2017- 5 Ocak 2018 tarihleri arasındaki döviz kuru baz alınarak yaklaşık bir değer ile Türk Lirasına (TL) çevrilmiştir (1 Dolar=3,8 TL; 1 Euro=4,5 TL).

Katılımcıların ikamet ettiği ülkelere göre ortalama harcamaları Tablo 12 'de gösterilmektedir.

\begin{tabular}{|c|c|c|c|c|c|c|c|c|c|c|c|c|}
\hline \multirow[b]{2}{*}{ Ülkeler } & \multicolumn{11}{|c|}{ HARCAMA (TL) } & \multirow[b]{2}{*}{ 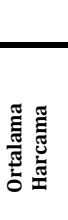 } \\
\hline & 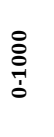 & 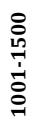 & 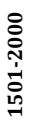 & 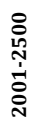 & 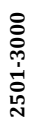 & 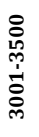 & 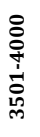 & 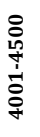 & 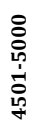 & $\begin{array}{l}8 \\
0 \\
0 \\
\stackrel{1}{0} \\
\stackrel{0}{0}\end{array}$ & 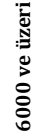 & \\
\hline Fransa & 5 & 1 & 0 & 0 & 0 & 1 & 2 & 1 & 0 & 3 & 17 & 5790 \\
\hline Belçika & 1 & 1 & 0 & 3 & 0 & 6 & 1 & 3 & 1 & 5 & 8 & 5171 \\
\hline Hollanda & 10 & 3 & 0 & 3 & 0 & 1 & 5 & 1 & 0 & 1 & 14 & 4506 \\
\hline Arabistan & 8 & 2 & 4 & 0 & 0 & 2 & 2 & 0 & 2 & 1 & 5 & 3853 \\
\hline Misır & 4 & 0 & 1 & 0 & 1 & 3 & 2 & 3 & 2 & 3 & 2 & 3661 \\
\hline Katar & 7 & 2 & 0 & 0 & 0 & 1 & 2 & 0 & 0 & 0 & 4 & 3153 \\
\hline
\end{tabular}




\begin{tabular}{|l|c|c|c|c|c|c|c|c|c|c|c|c|}
\hline Almanya & 13 & 1 & 1 & 0 & 1 & 0 & 0 & 1 & 0 & 0 & 4 & 2353 \\
\hline KKTC & 95 & 31 & 10 & 8 & 7 & 2 & 4 & 4 & 3 & 3 & 3 & 1459 \\
\hline Azerbayc. & 6 & 3 & 1 & 0 & 1 & 2 & 0 & 0 & 0 & 0 & 0 & 1448 \\
\hline Türkiye & 74 & 15 & 9 & 3 & 3 & 0 & 0 & 0 & 2 & 0 & 1 & 1025 \\
\hline Gürcistan & 14 & 11 & 1 & 0 & 0 & 0 & 0 & 0 & 0 & 0 & 0 & 909 \\
\hline Suriye & 40 & 4 & 0 & 2 & 0 & 1 & 0 & 0 & 0 & 0 & 0 & 657 \\
\hline Diğer & 14 & 11 & 9 & 4 & 5 & 3 & 3 & 1 & 0 & 3 & 3 & 2452 \\
\hline Toplam & $\mathbf{2 9 1}$ & $\mathbf{8 5}$ & $\mathbf{3 6}$ & $\mathbf{2 3}$ & $\mathbf{1 8}$ & $\mathbf{2 2}$ & $\mathbf{2 1}$ & $\mathbf{1 4}$ & $\mathbf{1 0}$ & $\mathbf{1 9}$ & $\mathbf{6 1}$ & $\mathbf{2 2 3 2}$ \\
\hline
\end{tabular}

Tablo 12'ye göre kişi başı ortalama harcamanın en yüksek olduğu ülkeler sırasıyla Fransa, Belçika, Hollanda, Arabistan ve Mısır'dır. Tablo 12 incelendiğinde Hollanda, Fransa, Belçika'da ikamet eden katılımcıların daha çok 6000 TL ve üzeri harcama yaptıkları, KKTC, Türkiye, Almanya ve Suriye'de ikamet eden katılımcıların çoğunlukla 500 TL'nin altında harcama yaptıkları dikkat çekmektedir. Tabloda yer alan bilgilere göre Gürcistan'da ikamet eden katılımcıların çoğunun 1000-1500 TL arası harcama yaptıkları, Azerbaycan'da ikamet eden katılımcıların 3500 TL üzerinde harcama yapmadıkları söylenebilir. Mısır, Katar ve Arabistan'da ikamet eden katılımcıların harcama aralığ ise değişiklik göstermektedir.

Tablo 13-14 katılımcıların ikamet ettikleri ülkeler bazında harcama dağılımları ile ilgili bilgileri göstermektedir.

\begin{tabular}{|c|c|c|c|c|c|}
\hline $\begin{array}{l}\text { Harcama } \\
\text { Kalemleri }\end{array}$ & $\begin{array}{l}\text { Ortalama } \\
\text { (Mean) }\end{array}$ & Sayı $(N)$ & $\begin{array}{c}\text { Minimum } \\
\text { Harcama } \\
(\mathrm{TL}) \\
\end{array}$ & $\begin{array}{c}\text { Maksimum } \\
\text { Harcama } \\
\text { (TL) }\end{array}$ & Toplam Harcama (TL) \\
\hline Konaklama & 507,61 & 21 & 80 & 3.600 & 10.660 \\
\hline Yiyecek-İçecek & 285,53 & 103 & 30 & 2.000 & 29.410 \\
\hline Ulaşım & 123,28 & 73 & 20 & 600 & 9.000 \\
\hline Sağlık & 95 & 6 & 80 & 130 & 570 \\
\hline Eğlence & 405,32 & 14 & 50 & 8.000 & 31.210 \\
\hline Kültür/Etkinlik & 70,71 & 14 & 30 & 200 & 990 \\
\hline Giyim & 341,53 & 26 & 80 & 1200 & 8.800 \\
\hline Kişisel Bakım & 148,08 & 47 & 20 & 500 & 6.960 \\
\hline Alkol/Tütün & 72,75 & 29 & 20 & 200 & 2.110 \\
\hline Kiralık Araç & 303,75 & 4 & 75 & 850 & 1.215 \\
\hline İletişim & 177,5 & 4 & 30 & 600 & 710 \\
\hline Gazete/Dergi & - & - & - & - & \\
\hline Hediyelik Eşya & 176,77 & 45 & 20 & 500 & 7.955 \\
\hline $\begin{array}{l}\text { Türkiye } \\
\text { (Genel) }\end{array}$ & $1.024,95$ & 107 & 30 & 11.800 & 109.670 \\
\hline
\end{tabular}

Tablo 13 incelendiğinde Türkiye'de ikamet eden katılımcıların Adana'yı ziyaretleri süresince toplam harcamaları 109.670 TL'dir. Bu rakam içerisinde 31 bin TL'ni aşkın tutar ile en çok harcama yapılan kalem eğlencedir. Katılımcıların neredeyse tamamı yiyecek içecek için harcama yaparken, gazete ve dergi için harcama yapan hiç katılımcı olmadı̆̆ dikkat çekmektedir. Harcama kalemlerine ilişkin ortalama harcama tutarları dikkate alındığında ise sinema ve tiyatro gibi kültürel etkinlikler en az kişi başı ortalama harcama tutarına sahipken; en yüksek kişi başı ortalama harcama 507 TL ile konaklamaya aittir. 
Tablo 14. Kuzey Kıbrıs Türk Cumhuriyeti'nde İkamet Eden Katılımcıların Harcama Dağılımlarına İlişkin Bilgiler

\begin{tabular}{|l|l|l|l|l|l|}
\hline \multicolumn{1}{|c|}{$\begin{array}{c}\text { Karcama } \\
\text { Kalemleri }\end{array}$} & $\begin{array}{c}\text { Ortalama } \\
\text { (Mean) }\end{array}$ & $\begin{array}{c}\text { Sayı } \\
\text { (N) }\end{array}$ & $\begin{array}{c}\text { Minimum } \\
\text { Harcama (TL) }\end{array}$ & $\begin{array}{c}\text { Maksimum } \\
\text { Harcama (TL) }\end{array}$ & $\begin{array}{c}\text { Toplam } \\
\text { Harcama } \\
\text { (TL) }\end{array}$ \\
\hline Konaklama & 440,15 & 64 & 100 & 1.900 & 28.170 \\
\hline Yiyecek-İçecek & 390,30 & 165 & 40 & 8.000 & 64.400 \\
\hline Ulașım & 132,16 & 127 & 20 & 12.000 & 16.785 \\
\hline Sağlık & 148,82 & 17 & 30 & 600 & 2.530 \\
\hline Eğlence & 504,39 & 116 & 50 & 4.560 & 58.510 \\
\hline Kültür/Etkinlik & 68,92 & 13 & 3 & 380 & 896 \\
\hline Giyim & 537,44 & 43 & 80 & 1.710 & 23.110 \\
\hline Kișisel Bakım & 203,87 & 62 & 20 & 760 & 12.640 \\
\hline Alkol/Tütün & 83,93 & 49 & 20 & 300 & 4.113 \\
\hline Kiralık Araç & 416,36 & 22 & 100 & 1.140 & 9.160 \\
\hline İletișim & 70 & 4 & 30 & 100 & 280 \\
\hline Gazete/Dergi & - & - & - & - & 27.395 \\
\hline Hediyelik Eşya & 346,77 & 79 & 20 & 2.000 & 247.989 \\
\hline KKTC (Genel) & 1458,75 & 170 & 40 & 11.900 & \\
\hline
\end{tabular}

Tablo 14'e göre KKTC'de ikamet eden katılımcıların Adana'yı ziyaretleri süresince yaptıkları toplam harcama tutarı 247.989 TL'dir. Bu tutar içerisinde yiyecek içecek harcamaları 64.400 TL ile en yüksek paya sahip kalemdir. Türkiye'de ikamet eden katılımcılarda olduğu gibi gazete ve dergi için bir harcama yapılmadığı ve katılımcıların neredeyse tamamının yiyecek-içecek harcaması yapmış olduğu dikkat çekmektedir. Harcama kalemlerine ait kişi başı ortalama tutarlar incelendiğinde; en yüksek ortalama 537,44 TL ile giyime aitken, 68,92 TL ile sinema ve tiyatro gibi etkinlikler en az ortalamaya sahip harcama kalemidir.

\begin{tabular}{|l|c|c|c|c|c|}
\hline \multicolumn{1}{|c|}{ Tablo 15. Suriye'de İkamet Eden Katılımclların Harcama Dağllımlarına İlişkin Bilgiler } \\
\cline { 2 - 5 } & $\begin{array}{c}\text { Ortalama } \\
\text { (Mean) }\end{array}$ & Sayı (N) & $\begin{array}{c}\text { Minimum } \\
\text { Harcama } \\
\text { Tutarı (TL) }\end{array}$ & $\begin{array}{c}\text { Maksimum } \\
\text { Harcama } \\
\text { Tutarı (TL) }\end{array}$ & $\begin{array}{c}\text { Toplam } \\
\text { Harcanan } \\
\text { (TL) }\end{array}$ \\
\hline $\begin{array}{l}\text { Harcama } \\
\text { Kalemleri }\end{array}$ & 360,00 & 5 & 200 & 600 & 1.800 \\
\hline Konaklama & 171,33 & 45 & 40 & 600 & 7.710 \\
\hline Yiyecek-İçecek & 83,42 & 38 & 30 & 200 & 3.170 \\
\hline Ulaşım & 121,25 & 8 & 20 & 200 & 970 \\
\hline Sağlı & 248,27 & 29 & 100 & 650 & 7.200 \\
\hline Eğlence & 55 & 4 & 30 & 10 & 220 \\
\hline Kültür/Etkinlik & 298 & 10 & 90 & 700 & 2.980 \\
\hline Giyim & 120 & 12 & 40 & 400 & 1.440 \\
\hline Kişisel Bakı̈m & 72 & 20 & 30 & 150 & 1.440 \\
\hline Alkol/Tütün & - & - & - & - & - \\
\hline Kiralı Araç & 60,71 & 7 & 30 & 100 & 425 \\
\hline İletișim & - & - & - & - & - \\
\hline Gazete/Dergi & 221,25 & 16 & 90 & 1.200 & 3.540 \\
\hline Hediyelik Eșya & 657,34 & 47 & 0,00 & 2.400 & $\mathbf{3 0 . 8 9 5}$ \\
\hline Suriye (Genel) & & & & & \\
\hline
\end{tabular}


Tablo 15’e göre Suriye'de ikamet eden katılımcıların Adana'yı ziyaretleri süresince yaptıkları toplam harcama tutarı 30.895 TL'dir. Bu tutar içerisinde yiyecek içecek harcamaları 7.710 TL ve eğlence harcamaları 7200 TL ile en yüksek paya sahip kalemlerdir. Türkiye ve KKTC'de ikamet eden katılımcılarda olduğu gibi gazete ve dergi için bir harcama yapılmadığı ve katılımcıların neredeyse tamamının yiyecek-içecek harcaması yapmış olduğu dikkat çekmektedir. Suriye'de ikamet eden katılımcılar kiralık araç için de herhangi bir harcama yapmamışlardır. Harcama kalemlerine ait kişi başı ortalama tutarlar incelendiğinde; en yüksek ortalama 360 TL ile konaklamaya aitken, 55 TL ile sinema ve tiyatro gibi etkinlikler en az ortalamaya sahip harcama kalemidir.

\begin{tabular}{|l|c|c|c|c|c|}
\hline Tablo 16. Hollanda'da İkamet Eden Katılımcıların Harcama Dağılımlarına İlişkin Bilgiler \\
\cline { 1 - 5 } & $\begin{array}{c}\text { Ortalama } \\
\text { (Mean) }\end{array}$ & Sayı (N) & $\begin{array}{c}\text { Minimum } \\
\text { Harcama } \\
\text { Tutarı (TL) }\end{array}$ & $\begin{array}{c}\text { Maksimum } \\
\text { Harcama } \\
\text { Tutarı (TL) }\end{array}$ & $\begin{array}{c}\text { Toplam } \\
\text { Harcanan } \\
\text { (TL) }\end{array}$ \\
\hline $\begin{array}{l}\text { Harcama } \\
\text { Kalemleri }\end{array}$ & 531,81 & 11 & 300 & 1.000 & 5.850 \\
\hline Konaklama & 982,89 & 38 & 100 & 2.700 & 37.350 \\
\hline Yiyecek-İçecek & 126,15 & 13 & 25 & 225 & 1.640 \\
\hline Ulaşım & 100 & 1 & 100 & 1 & 100 \\
\hline Sağlık & 877,5 & 36 & 100 & 2.700 & 31.590 \\
\hline Eğlence & 35 & 4 & 30 & 50 & 140 \\
\hline Kültür/Etkinlik & $1.556,81$ & 22 & 100 & 3.150 & 34.250 \\
\hline Giyim & 666,66 & 24 & 30 & 1.350 & 16.000 \\
\hline Kișisel Bakım & 200 & 3 & 150 & 225 & 600 \\
\hline Alkol/Tütün & 997,27 & 22 & 290 & 1.800 & 21.940 \\
\hline Kiralık Araç & 55 & 2 & 50 & 60 & 110 \\
\hline İletişim & - & - & - & - & - \\
\hline Gazete/Dergi & 746,72 & 29 & 60 & 1800 & 21.655 \\
\hline Hediyelik Eşya & $4.505,92$ & 38 & 400 & 11025 & $\mathbf{1 7 1 . 2 2 5}$ \\
\hline $\begin{array}{l}\text { Hollanda } \\
\text { (Genel) }\end{array}$ & & & & & \\
\hline
\end{tabular}

Tablo 16 incelendiğinde Hollanda'da ikamet eden katılımcıların Adana'yı ziyaretleri süresince toplam harcamaları 171.225 TL'dir. Bu rakam içerisinde 37.350 TL'ni ile en çok harcama yapılan kalem yiyecek-içecektir. Katılımcıların tamamı yiyecek içecek için harcama yaparken, gazete ve dergi için harcama yapan katılımcı olmadığı dikkat çekmektedir. Harcama kalemlerine ilişkin ortalama harcama tutarları dikkate alındığında ise sinema ve tiyatro gibi kültürel etkinlikler en az kişi başı ortalama harcama tutarına sahipken; en yüksek kişi başı ortalama harcama 1556,81 TL ile giyime aittir. 


\begin{tabular}{|l|c|c|c|c|c|}
\hline \multicolumn{1}{|c|}{ Tablo 17. Arabistan'da İkamet Eden Katılımcıların Harcama Dağılımlarına İlișkin Bilgiler } \\
\cline { 2 - 6 } & $\begin{array}{c}\text { Ortalama } \\
\text { (Mean) }\end{array}$ & $\begin{array}{c}\text { Sayı } \\
\text { (N) }\end{array}$ & $\begin{array}{c}\text { Minimum Harcama } \\
\text { Tutarı (TL) }\end{array}$ & $\begin{array}{c}\text { Maksimum } \\
\text { Harcama } \\
\text { Tutarı (TL) }\end{array}$ & $\begin{array}{c}\text { Toplam } \\
\text { Harcanan } \\
\text { (TL) }\end{array}$ \\
\hline $\begin{array}{l}\text { Harcama } \\
\text { Kalemleri }\end{array}$ & $1.706,92$ & 13 & 300 & 4.560 & 22.190 \\
\hline Konaklama & $1.137,23$ & 26 & 100 & 4.000 & 29.568 \\
\hline Yiyecek-İçecek & 151,33 & 15 & 40 & 600 & 2.270 \\
\hline Ulaşım & 2000 & 1 & 2.000 & 2.000 & 2.000 \\
\hline Sağlı & 631,05 & 19 & 100 & 1.900 & 11.990 \\
\hline Eğlence & 67,5 & 4 & 20 & 100 & 270 \\
\hline Kültür/Etkinlik & 855,55 & 9 & 90 & 2.660 & 7.700 \\
\hline Giyim & 670 & 9 & 150 & 2.660 & 6.030 \\
\hline Kişisel Bakım & 187,5 & 4 & 120 & 300 & 750 \\
\hline Alkol/Tütün & 658,57 & 7 & 450 & 900 & 4.610 \\
\hline Kiralık Araç & - & - & - & - & - \\
\hline İletișim & - & - & - & - & - \\
\hline Gazete/Dergi & 753,52 & 17 & 100 & 4560 & 12.810 \\
\hline Hediyelik Eșya & $3.853,38$ & 26 & 200 & 16.420 & $\mathbf{1 0 0 . 1 8 8}$ \\
\hline $\begin{array}{l}\text { Arabistan } \\
\text { (Genel) }\end{array}$ & & & & & \\
\hline
\end{tabular}

Tablo 17'ye göre Arabistan'da ikamet eden katılımcların Adana'yı ziyaretleri süresince yaptıkları toplam harcama tutarı 100.188 TL'dir. Bu tutar içerisinde yiyecek içecek harcamaları 29.568 TL ile en yüksek paya sahip kalemdir. Gazete ve dergi ile iletişim için bir harcama yapılmadığı ve katılımcıların tamamının yiyecek-içecek harcaması yapmış olduğu dikkat çekmektedir. Harcama kalemlerine ait kişi başı ortalama tutarlar incelendiğinde; en yüksek ortalama 1706,92 TL ile konaklamaya aitken, 67,5 TL ile sinema ve tiyatro gibi etkinlikler en az ortalamaya sahip harcama kalemidir.

\begin{tabular}{|l|c|c|c|c|c|}
\hline \multicolumn{6}{|c|}{ Tablo 18. Gürcistan'da İkamet Eden Katılımcıların Harcama Dağılımlarına İlisskin Bilgiler } \\
\hline $\begin{array}{l}\text { Harcama } \\
\text { Kalemleri }\end{array}$ & $\begin{array}{c}\text { Ortalama } \\
\text { (Mean) }\end{array}$ & Sayı (N) & $\begin{array}{c}\text { Minimum } \\
\text { Harcama } \\
\text { Tutarı (TL) }\end{array}$ & $\begin{array}{c}\text { Maksimum } \\
\text { Harcama } \\
\text { Tutarı (TL) }\end{array}$ & $\begin{array}{c}\text { Toplam } \\
\text { Harcanan } \\
\text { (TL) }\end{array}$ \\
\hline Konaklama & 315 & 6 & 140 & 600 & 1.890 \\
\hline Yiyecek-İçecek & 270,76 & 26 & 100 & 500 & 7.040 \\
\hline Ulaşım & 119,44 & 18 & 50 & 500 & 2.150 \\
\hline Sağlı & 80 & 1 & 80 & 80 & 80 \\
\hline Eğlence & 270,45 & 22 & 100 & 500 & 5.950 \\
\hline Kültür/Etkinlik & 80 & 2 & 60 & 100 & 160 \\
\hline Giyim & 200 & 1 & 200 & 200 & 200 \\
\hline Kişisel Bakım & 90 & 7 & 60 & 200 & 630 \\
\hline Alkol/Tütün & 114 & 10 & 50 & 200 & 1.140 \\
\hline Kiralık Araç & 323,33 & 3 & 220 & 450 & 970 \\
\hline İletișim & - & - & - & - & - \\
\hline Gazete/Dergi & - & - & - & - & - \\
\hline Hediyelik Eșya & 228,66 & 15 & 50 & 760 & 3.430 \\
\hline $\begin{array}{l}\text { Gürcistan } \\
\text { (Genel) }\end{array}$ & 909,23 & 26 & 330 & 1720 & $\mathbf{2 3 . 6 4 0}$ \\
\hline
\end{tabular}


Tablo 18 incelendiğinde Gürcistan'da ikamet eden katılımcıların Adana'yı ziyaretleri süresince toplam harcamaları 23.640 TL'dir. Bu rakam içerisinde 7.040 TL ile en çok harcama yapılan kalem yiyecek-içecektir. Katılımcıların tamamı yiyecek içecek için harcama yaparken, gazete ve dergi ile iletişim için harcama yapan katılımcı olmadığı dikkat çekmektedir. Sağlık, giyim, kültürel etkinlikler ve araç kiralama harcamaları en az katılım gören harcamalardır. Harcama kalemlerine ilişkin ortalama harcama tutarları dikkate alındığında ise sinema ve tiyatro gibi kültürel etkinlikler en az kişi başı ortalama harcama tutarına sahipken; en yüksek kişi başı ortalama harcama 323,33 TL ile araç kiralamaya aittir.

\begin{tabular}{|l|c|c|c|c|c|}
\hline \multicolumn{2}{|l|}{ Tablo 19. Azerbaycan'da İkamet Eden Katılımcıların Harcama Dağılımlarına Ilisskin Bilgiler } \\
\hline & $\begin{array}{c}\text { Ortalama } \\
\text { (Mean) }\end{array}$ & Sayı (N) & $\begin{array}{c}\text { Minimum } \\
\text { Harcama } \\
\text { Tutarı (TL) }\end{array}$ & $\begin{array}{c}\text { Maksimum } \\
\text { Harcama } \\
\text { Tutarı (TL) }\end{array}$ & $\begin{array}{c}\text { Toplam } \\
\text { Harcanan } \\
\text { (TL) }\end{array}$ \\
\hline $\begin{array}{l}\text { Harcama } \\
\text { Kalemleri }\end{array}$ & 810 & 5 & 270 & 1.500 & 4.050 \\
\hline Konaklama & 355 & 12 & 80 & 1.000 & 4.260 \\
\hline Yiyecek-İçecek & 151 & 10 & 50 & 300 & 1.510 \\
\hline Ulașım & - & - & - & - & - \\
\hline Sağlık & 264 & 10 & 120 & 450 & 2.640 \\
\hline Eğlence & 40 & 3 & 40 & 40 & 120 \\
\hline Kültür/Etkinlik & 250 & 5 & 100 & 400 & 1.250 \\
\hline Giyim & 177,14 & 7 & 50 & 400 & 1.240 \\
\hline Kișisel Bakım & 67,5 & 4 & 50 & 100 & 270 \\
\hline Alkol/Tütün & 600 & 2 & 600 & 600 & 1.200 \\
\hline Kiralık Araç & - & - & - & - & - \\
\hline Illetișim & 10 & 2 & 10 & 10 & 20 \\
\hline Gazete/Dergi & 251,11 & 9 & 50 & 550 & 2.260 \\
\hline Hediyelik Eşya & $1.447,69$ & 13 & 100 & 3.300 & $\mathbf{1 8 . 8 2 0}$ \\
\hline $\begin{array}{l}\text { Azerbaycan } \\
\text { (Genel) }\end{array}$ & & & & & \\
\hline
\end{tabular}

Tablo 19'a göre Azerbaycan'da ikamet edip Adana'yı ziyaret eden katılımcıların tatil süreçlerinde yaptıkları toplam harcama tutarı 18.820 TL'dir. Bu tutar içerisinde en yüksek harcama payı 4260 TL ile yiyecek içecek ve 4050 TL ile konaklamaya aittir. Sağlık ve iletişim için herhangi bir harcama yapılmadığı tablodan elde edilen bilgilerde yer almaktadır. Katılımcı sayısı bağlamında en fazla harcama yapılan kalemler yeme-içme, ulaşım, eğlence ve hediyelik eşyalardır. Kişi başı ortalama harcamalar izlendiğinde en fazla ortalama 810 TL ile konaklamaya ait iken; en az kişi bașı ortalama harcama 10 TL ile gazete ve dergiye aittir. 


\begin{tabular}{|l|c|c|c|c|c|}
\hline \multicolumn{2}{|l|}{ Tablo 20. Katar'da İkamet Eden Katılımcıların Harcama Dağılımlarına İlişkin Bilgiler } \\
\cline { 2 - 5 } & $\begin{array}{c}\text { Ortalama } \\
\text { (Mean) }\end{array}$ & Sayı (N) & $\begin{array}{c}\text { Minimum } \\
\text { Harcama } \\
\text { Tutarı (TL) }\end{array}$ & $\begin{array}{c}\text { Maksimum } \\
\text { Harcama } \\
\text { Tutarı (TL) }\end{array}$ & $\begin{array}{c}\text { Toplam } \\
\text { Harcanan } \\
\text { (TL) }\end{array}$ \\
\hline Konaklama & 838 & 10 & 180 & 1.520 & 8.380 \\
\hline Yiyecek-İçecek & 718,66 & 15 & 100 & 2.660 & 10.780 \\
\hline Ulaşım & 110 & 7 & 40 & 250 & 770 \\
\hline Sağlık & - & - & - & - & - \\
\hline Ĕglence & 953,75 & 8 & 200 & 2.470 & 7.630 \\
\hline Kültür/Etkinlik & - & - & - & - & - \\
\hline Giyim & 1.014 & 10 & 50 & 2.280 & 10.140 \\
\hline Kișisel Bakım & 380,7 & 10 & 90 & 950 & 3.800 \\
\hline Alkol/Tütün & 162,5 & 4 & 30 & 380 & 650 \\
\hline Kiralık Araç & 840 & 7 & 180 & 1.140 & 5.880 \\
\hline İletiş̧im & - & - & - & - & - \\
\hline Gazete/Dergi & 18 & 1 & 18 & 18 & 18 \\
\hline Hediyelik Eșya & 298,75 & 8 & 150 & 570 & 2.390 \\
\hline Katar (Genel) & $3.152,81$ & 16 & 350 & 10.220 & $\mathbf{5 0 . 4 4 5}$ \\
\hline
\end{tabular}

Tablo 20'ye göre Katar'da ikamet eden katılımcıların Adana'yı ziyaretleri süresince yaptıkları toplam harcama tutarı 50.445 TL'dir. Bu tutar içerisinde 10.780 TL ile yiyecek içecek harcamaları ve 10.140 TL giyim harcamaları en yüksek paya sahip kalemlerdir. Sağlık, kültürel etkinlikler ve iletişim için bir harcama yapılmadığı ve katılımcıların neredeyse tamamının yiyecek-içecek harcaması yapmış olduğu dikkat çekmektedir. Harcama kalemlerine ait kişi başı ortalama tutarlar incelendiğinde; en yüksek ortalama 1.104 TL ile giyime ait iken, 18 TL ile gazete-dergi ve 110 TL ile ulaşım harcamaları en az ortalamaya sahip harcama kalemidir.

\begin{tabular}{|c|c|c|c|c|c|}
\hline $\begin{array}{l}\text { Harcama } \\
\text { Kalemleri }\end{array}$ & $\begin{array}{c}\text { Ortalama } \\
\text { (Mean) }\end{array}$ & Sayı (N) & $\begin{array}{c}\text { Minimum } \\
\text { Harcama } \\
\text { Tutarı (TL) }\end{array}$ & $\begin{array}{c}\text { Maksimum } \\
\text { Harcama } \\
\text { Tutarı (TL) }\end{array}$ & $\begin{array}{c}\text { Toplam } \\
\text { Harcanan } \\
\text { (TL) }\end{array}$ \\
\hline Konaklama & $1.070,88$ & 17 & 250 & 2.280 & 18.205 \\
\hline Yiyecek-İçecek & 817 & 20 & 100 & 2.280 & 16.340 \\
\hline Ulașım & 127,77 & 9 & 60 & 300 & 1.150 \\
\hline Sağllk & - & - & - & - & - \\
\hline Eğlence & 663,05 & 18 & 200 & 1.200 & 11.935 \\
\hline Kültür/Etkinlik & 40 & 1 & 40 & 40 & 40 \\
\hline Giyim & 738 & 10 & 250 & 1.400 & 7.380 \\
\hline Kișisel Bakım & 381,42 & 14 & 150 & 600 & 5.340 \\
\hline Alkol/Tütün & - & - & - & - & - \\
\hline Kiralık Araç & 581,66 & 12 & 300 & 1.500 & 6.980 \\
\hline İletișim & - & - & - & - & - \\
\hline Gazete/Dergi & - & - & - & - & - \\
\hline Hediyelik Essya & 523,75 & 16 & 100 & 950 & 8.380 \\
\hline Misır (Genel) & $3.661,42$ & 21 & 540 & 7.040 & 76.890 \\
\hline
\end{tabular}


Tablo 21 incelendiğinde Mısır'da e ikamet eden katılımcıların Adana'yı ziyaretleri süresince toplam harcamaları 76.980TL'dir. Bu rakam içerisinde 18.205 TL ile en çok harcama yapılan kalem konaklamadır. Katılımcıların neredeyse tamamı yiyecek içecek için harcama yaparken, sağlık, iletişim, gazete ve dergi ile iletişim için harcama yapan katılımcı olmadığı dikkat çekmektedir. Harcama kalemlerine ilişkin ortalama harcama tutarları dikkate alındığında ise sinema ve tiyatro gibi kültürel etkinlikler ile kişisel bakım harcamaları en az kişi başı ortalama harcama tutarına sahipken; en yüksek kişi başı ortalama harcama 1.070,88 TL ile araç kiralamaya aittir.

\begin{tabular}{|c|c|c|c|c|c|}
\hline $\begin{array}{l}\text { Harcama } \\
\text { Kalemleri }\end{array}$ & $\begin{array}{c}\text { Ortalama } \\
\text { (Mean) }\end{array}$ & Sayı (N) & $\begin{array}{c}\text { Minimum } \\
\text { Harcama } \\
\text { Tutarı (TL) }\end{array}$ & $\begin{array}{c}\text { Maksimum } \\
\text { Harcama } \\
\text { Tutarı (TL) }\end{array}$ & $\begin{array}{c}\text { Toplam } \\
\text { Harcanan } \\
\text { (TL) }\end{array}$ \\
\hline Konaklama & $1.208,57$ & 7 & 180 & 2.025 & 8.460 \\
\hline Yiyecek-İçecek & $1.372,16$ & 30 & 80 & 4.500 & 41.165 \\
\hline Ulașım & 244,54 & 11 & 40 & 675 & 2.690 \\
\hline Sağlık & - & - & - & - & - \\
\hline Eğlence & 1.439 & 25 & 200 & 3.150 & 35.975 \\
\hline Kültür/Etkinlik & 50 & 1 & 50 & 50 & 50 \\
\hline Giyim & $1.365,47$ & 21 & 250 & 3.150 & 28.675 \\
\hline Kișisel Bakım & 760 & 25 & 50 & 1.575 & 19.000 \\
\hline Alkol/Tütün & 145 & 3 & 60 & 225 & 435 \\
\hline Kiralık Araç & 972 & 16 & 160 & 1.350 & 15.560 \\
\hline İletișim & - & - & - & - & - \\
\hline Gazete/Dergi & - & - & - & - & - \\
\hline Hediyelik Eșya & 867,80 & 25 & 100 & 4.500 & 21.695 \\
\hline Fransa (Genel) & $5.790,16$ & 30 & 180 & 13.500 & 173.705 \\
\hline
\end{tabular}

Tablo 22'ye göre Fransa'da ikamet edip Adana'yı ziyaret eden katılımcıların tatil süreçlerinde yaptıkları toplam harcama tutarı 173.705 TL'dir. Bu tutar içerisinde en yüksek harcama payı 41.165 TL ile yiyecek içecek ve 35.975 TL ile eğlenceye aittir. Sağlık, iletişim, gazete ve dergi için herhangi bir harcama yapılmadığı tablodan elde edilen bilgilerde yer almaktadır. Katılımcı sayısı bağlamında en az harcama yapılan kalemler kültür/etkinlik ile alkol/tütündür. Kişi başı ortalama harcamalar izlendiğinde en fazla ortalama 1365,47 TL ile giyime ait iken; en az kişi başı ortalama harcama 145 TL ile alkol ve tütün harcamalarına aittir.

\begin{tabular}{|l|c|c|c|c|c|}
\hline \multicolumn{2}{|c|}{ Tablo 23. Belçika'da İkamet Eden Katılımcıların Harcama Dağılımlarına İlișkin Bilgiler } \\
\cline { 1 - 5 } & $\begin{array}{c}\text { Ortalama } \\
\text { (Mean) }\end{array}$ & Sayı (N) & $\begin{array}{c}\text { Minimum } \\
\text { Harcama } \\
\text { Tutarı (TL) }\end{array}$ & $\begin{array}{c}\text { Maksimum } \\
\text { Harcama } \\
\text { Tutarı (TL) }\end{array}$ & $\begin{array}{c}\text { Toplam } \\
\text { Harcanan } \\
\text { (TL) }\end{array}$ \\
\hline $\begin{array}{l}\text { Harcama } \\
\text { Kalemleri }\end{array}$ & 925 & 8 & 500 & 1.300 & 7.400 \\
\hline Konaklama & $1.137,58$ & 29 & 100 & 3.150 & 32.990 \\
\hline Yiyecek-İçecek & 150 & 1 & 150 & 150 & 150 \\
\hline Ulașım & 375 & 4 & 150 & 600 & 1.500 \\
\hline Sağlık & $1.093,51$ & 27 & 200 & 2.700 & 29.525 \\
\hline Eğlence & & & & & \\
\hline
\end{tabular}




\begin{tabular}{|l|c|c|c|c|c|}
\hline Kültür/Etkinlik & - & - & - & - & - \\
\hline Giyim & $1.183,33$ & 21 & 200 & 2.700 & 24.850 \\
\hline Kișisel Bakım & 514,61 & 26 & 30 & 1.575 & 13.380 \\
\hline Alkol/Tütün & 450 & 1 & 450 & 450 & 450 \\
\hline Kiralık Araç & 773,95 & 24 & 150 & 1.800 & 18.575 \\
\hline İletișim & - & - & - & - & - \\
\hline Gazete/Dergi & - & - & - & - & - \\
\hline Hediyelik Eșya & 782,96 & 27 & 50 & 1.800 & 21.140 \\
\hline Belçika (Genel) & $5.171,03$ & 29 & 540 & 10.350 & $\mathbf{1 4 9 . 9 6 0}$ \\
\hline
\end{tabular}

Tablo 23 incelendiğinde Belçika'da ikamet eden katılımcıların Adana'yı ziyaretleri süresince toplam harcamaları 149.960 TL'dir. Bu rakam içerisinde 32.990 TL ile en çok harcama yapılan kalem yeme-içmedir. Katılımcıların tamamı yiyecek içecek için harcama yaparken; kültür/etkinlik, iletişim, gazete ve dergi ile iletişim için harcama yapan katılımcı olmadığı dikkat çekmektedir. Harcama kalemlerine ilişkin ortalama harcama tutarları dikkate alındığında ise sağlık ve ulaşım harcamaları en az kişi başı ortalama harcama tutarına sahipken; en yüksek kişi başı ortalama harcama 1.183,33 TL ile giyim, 1.137,58 TL ile yeme-içme ve 1.093,51 TL ile eğlenceye aittir.

\begin{tabular}{|c|c|c|c|c|c|}
\hline $\begin{array}{l}\text { Harcama } \\
\text { Kalemleri }\end{array}$ & $\begin{array}{c}\text { Ortalama } \\
\text { (Mean) }\end{array}$ & Sayı (N) & $\begin{array}{l}\text { Minimum } \\
\text { Harcama } \\
\text { Tutarı (TL) }\end{array}$ & $\begin{array}{l}\text { Maksimum } \\
\text { Harcama } \\
\text { Tutarı (TL) }\end{array}$ & $\begin{array}{c}\text { Toplam } \\
\text { Harcanan } \\
\text { (TL) }\end{array}$ \\
\hline Konaklama & 350 & 1 & 350 & 350 & 350 \\
\hline Yiyecek-İçecek & 730 & 21 & 60 & 4.500 & 15.330 \\
\hline Ulașım & 155,55 & 9 & 100 & 300 & 1.400 \\
\hline Sağlık & 90 & 1 & 90 & 90 & 90 \\
\hline Eğlence & 729,06 & 16 & 50 & 4.500 & 11.665 \\
\hline Kültür/Etkinlik & 86,66 & 3 & 60 & 100 & 260 \\
\hline Giyim & 904,44 & 9 & 50 & 2.280 & 8.140 \\
\hline Kișisel Bakım & 483,33 & 12 & 40 & 2.700 & 5.800 \\
\hline Alkol/Tütün & 93,33 & 6 & 40 & 190 & 560 \\
\hline Kiralık Araç & 425 & 2 & 250 & 600 & 850 \\
\hline İletișim & 30 & 1 & 30 & 30 & 30 \\
\hline Gazete/Dergi & 30 & 2 & 30 & 30 & 60 \\
\hline Hediyelik Eşya & 405,83 & 12 & 100 & 1.575 & 4.870 \\
\hline $\begin{array}{l}\text { Almanya } \\
\text { (Genel) }\end{array}$ & $2.353,61$ & 21 & 200 & 9700 & 49.405 \\
\hline
\end{tabular}

Tablo 24'e göre Almanya'da ikamet edip Adana'yı ziyaret eden katılımcıların tatil süreçlerinde yaptıkları toplam harcama tutarı 49.405 TL'dir. $\mathrm{Bu}$ tutar içerisinde en yüksek harcama payı 15.330 TL ile yiyecek içecek ve 11.665 TL ile eğlenceye aittir. Katılımcı sayısı bağlamında en az harcama yapılan kalemler konaklama, sağlık, iletişim, kiralık araç, gazete ve dergidir. Kişi başı ortalama harcamalar izlendiğinde en fazla ortalama 904,44 TL ile giyime ait iken; en az kişi başı ortalama harcama 30 TL ile iletişim ile gazete ve dergi harcamalarma aittir. 


\subsubsection{Araştırma Verilerinden Elde Edilen Diğer Bulgular}

Araştırmada elde edilen verilere göre araştırmaya katılan 600 katılımcının toplam harcamaları 1.339.202 TL'dir. Katılımcıların kişi başı ortalama harcamaları 2232 TL olup, en fazla ortalamaya sahip olan harcama kalemleri kişi başı ortalama 861,26 TL ile giyim, 669,22 TL ile konaklama ve 604,70 TL ile eğlencedir. Katılımcı sayısı bağlamında en çok harcama yapılan alan 582 katılımcı ile yeme-içmedir ve ortalama kişi başı harcama tutarı 552,44 TL'dir. Ayrıca yiyecek içecek harcamaları toplam harcamadaki en büyük harcama kalemini oluşturmaktadır ve bu kaleme ayrılan toplam harcama tutarı 321.523 TL'dir. Bu rakamı 272.720 TL ile eğlence, 177.420 TL ile giyim, 153.355 TL ile hediyelik eşya ve 129.160 TL ile konaklama harcamaları takip etmektedir.

Katılımcılar arasında en yüksek kişi başı ortalama 5790,16 TL ile Fransa, 5171,03 TL ile Belçika ve 4505,92 TL ile Hollanda'ya aittir. Toplam harcama tutarları baz alındığında ise en yüksek harcama tutarı 247.989 TL ile KKTC, 173.705 TL ile Fransa ve 171.225 TL ile Hollanda'dır. En yüksek kişi başı ortalamalar ile harcama kalemleri ele alındığında yiyecek içecek için en yüksek ortalama 1372,16 TL ile Fransa'da ikamet eden katılımcılara aittir. Diğer harcama kalemleri için ise elde edilen bulgular şöyledir: konaklama 1706,92 TL ile Arabistan, ulaşım 244,54 TL ile Fransa, sağlı 2000 TL ile Arabistan, eğlence 1439 TL ile Fransa, Kültür/Etkinlik 200 TL ile Japonya, giyim 1556,81 TL ile Hollanda, kişisel bakım 766,25 TL ile Ukrayna, Tütün/alkol 450 TL ile Belçika, araç kiralama 997,27 TL ile Hollanda ve hediyelik eşya 867,8 TL ile Fransa'ya aittir. Ayrıca elde edilen veriler ışığında cezerye/lokum, salça, aksesuar, bijuteri ve bakliyatın Adana'dan götürülen hediyelik eşyalar arasında ilk sıralarda yer aldığını söylemek mümkündür.

\section{Sonuç ve Öneriler}

Turizm, özelinde destinasyonların, genelinde ise bölgelerin ve ülkelerin turistik arz kaynaklarını verimli bir şekilde kullanarak, bölgeler arasındaki dengesizliklerin giderilmesinde ve bölgesel kalkınmanın sağlanmasında önemli bir itici güce sahiptir. Turizm sektörü, hem gelişmiş, hem gelişmekte olan, hem de az gelişmiş ülkelerin ekonomilerinde de önemli bir yere sahiptir. Bu yüzden, bir yerin kalkınmasındaki turizmin rolü incelenirken o bölgeye gelen turistlerin harcama kalemlerinin incelenmesi ve bu doğrultuda turizm politikaların oluşturulmasının önemli olduğu düşünülmektedir. Adana'nın bölgesel kalkınmasında turizmin rolünü ölçmeyi hedefleyen bu çalışmada, Adana ilini ziyaret eden yerli ve yabancı turistlerin tatil süreçlerinde yaptıkları harcamalar tespit edilmeye çalışılmıştır.

Araştırmada elde edilen bulgular ışığında katılımcıların \%97 sinin yeme içme için harcama yaptığı dikkat çekmektedir. Bununla birlikte eğlence için katılımcıların \%75,2'si, ulaşım için katılımcıların \%61,5’i, hediyelik eşya için katılımcıların \%54,2'si, kişisel bakım için \%47 ve konaklama için katılımcıların 
\%32,2'si harcama yapmıștır. 600 katılımcının Adana'yı ziyaretlerinde harcadıkları toplam harcama tutarı 1.339.202 TL'dir. Bu harcama içerisinde en büyük pay 321.523 TL ile yeme-içme kalemine ait olup toplam harcama tutarının \%24'ünü ifade etmektedir. Yeme içmeden sonra en çok harcama yapılan kalem eğlence kalemidir. Eğlence için harcanan toplama harcama tutarı 272.720 TL'dir ve toplama harcamanın \%20,36'sını oluşturmaktadır. Giyim harcamaları toplam harcamanın \%13,24'ünü, hediyelik eşya \% 11,45'ini, konaklama harcamaları \%9,64'ünü, kişisel bakım harcamaları toplam harcamanın \%7,79'unu oluşturmaktadır.

Genel olarak değerlendirildiğinde Adana'ya 2017 yılında gelen turist sayısı 1.094.335 kişi ve araştırma çerçevesinde ortalama tespit edilen kişi başına harcama 2232 TL'dir. Gelen turist sayısının ortalama kişi başına harcamayla çarpılması sonucu yaklaşık 2,44 milyar TL/642 milyon $\$(1 \quad \$=3,8$ TL) doğrudan Adana ekonomisine katkı yaptığı görülmektedir. Kızıldemir'in 2015 yılında Adana ekonomisi üzerinde yaptığı çalışma sonuçlarına göre ortalama kişi başı turist harcaması 1578 TL, Adana ili yaklaşı turizm geliri 1,14 milyar TL'dir. Bu sonuçlardan da anlaşılacağı üzere; her ne kadar son yıllarda ülkede yaşanan sorunlar turist sayısını ülke genelinde etkilemiş olsa da; kent turizmi bağlamında gelişmeye devam eden Adana'da bu durum çok etki etmeden artışa yol açmıștır. Turizmin ekonomiye doğrudan, dolaylı ve uyarılmış etkileri düşünüldüğünde yaklaşık 2,44 milyar TL'nin Adana ekonomisinde daha fazla bir etki yapacağını söylemek mümkündür.

Araştırma evreni Adana ilinde ziyaret eden yerli ve yabancı turistler olup bu rakam 2017 yılı için 1.094.335 kişidir. Araştırmaya dahil olan 600 katılımcının 107'si Türkiye'de ikamet ederken, 493 katılımcının ülke dışında (Fransa, Belçika, Hollanda, Arabistan, Mısır, Katar, Almanya, KKTC, Azerbaycan, Gürcistan, Suriye) ikamet ettiği görülmektedir. Katılımcıların çoğu 18-25 yaş grubu arasında yer aldığı, cinsiyet farklılığı ile yaşları incelendiğinde kadınların çoğunun 18-25, erkeklerin çoğunun 51 yaş üzeri grupta yer aldığı, hem kadın hem de erkek katılımcıların çoğu evli olduğu saptanmıştır. Eğitim durumlarına bakıldığında ise eğitimsiz olanlar ile lisansüstü düzeyde eğitime sahip olanların azınlıkta olduğu dikkat çekmektedir. Eğitim düzeyinde katılım, hem erkeklerde hem de kadınlarda lisans düzeyinde çoğunluk gösterdiği görülmektedir. Katılımcılar arasında kadınların çoğunun çalışmadığı, çalışan kadınların ise çoğu memur olduğu, erkek katılımcılarda ise işçi ve kendi işi yapan katılımcılardan oluştuğu, Katılımcıların gelir düzeyleri incelendiğinde hem kadın hem de erkek katılımcılar kendilerinin orta düzey gelir seviyesinde oldukları tespit edilmiştir.

Adana'yı ziyaret eden katılımcıların seyahatleri ve seyahat süreçleri incelendiğinde katılımcıların \%44,8'i akraba veya arkadaş ziyareti; \%30,5'i tatil amaçlı Adana'ya geldikleri en az katılımın ise ticari ve kültürel nedenlerle olduğu tespit edilmiştir. Katılımcıların tatil sürelerinin bir günden bir aya kadar değişiklik gösterdiği dikkat çekerken, kişi başı ortalama tatil süresinin yaklaşık bir hafta olduğu saptanmıştır. Katılımcıların \%34'ü konaklamak için çeşitli büyüklükteki otelleri, pansiyonları ve kiralık evleri tercih ettikleri; \%65'inin 
aile, akraba veya arkadaşlarının evlerinde konaklama yaptıkları, çeşitli büyüklükteki otellerdeki kişi başı ortalama geceleme yaklaşık 4 gece, pansiyon ve kiralık evlerde ise kişi başı ortalama geceleme sayısı yaklaşık 18 iken aile, akraba ve arkadaş yanında tatillerini geçiren katılımcıların ortalama geceleme süresi ise 8,5 gece olduğu görülmektedir.

Katılımcıların ikamet ettiği ülkelere göre ortalama harcamaları incelendiğinde kişi başı ortalama harcamanın en yüksek olduğu ülkeler sırasıyla Fransa, Belçika, Hollanda, Arabistan ve Mısır'dır. Hollanda, Fransa, Belçika'da ikamet eden katılımcıların daha çok 6000 TL ve üzeri harcama yaptıkları, KKTC, Türkiye, Almanya ve Suriye'de ikamet eden katılımcıların çoğunlukla 500 TL'nin altında harcama yaptıkları dikkat çekmektedir. Gürcistan'da ikamet eden katılımcıların çoğunun 1000-1500 TL arası harcama yaptıkları, Azerbaycan'da ikamet eden katılımcıların 3500 TL üzerinde harcama yapmadıkları tespit edilmiştir.

Türkiye'de ikamet eden katılımcıların Adana'yı ziyaretleri süresince toplam harcamaları 109.670 TL olduğu bu rakam içerisinde 31 bin TL'ni aşkın tutar ile en çok harcama yapılan kalemin eğlence olduğu, KKTC'de ikamet eden katılımcıların toplam harcama tutarı 247.989 TL olduğu bu tutar içerisinde yiyecek içecek harcamaları 64.400 TL ile en yüksek paya sahip kalem olduğu saptanmıştır. Suriye'de ikamet eden katılımcıların toplam harcama tutarı 30.895 TL olduğu bu tutar içerisinde yiyecek içecek harcamaları 7.710 TL ve eğlence harcamaları 7200 TL ile en yüksek paya sahip kalemler olduğu, Hollanda'da ikamet eden katılımcıların toplam harcamalarının 171.225 TL olduğu ve bu rakam içerisinde 37.350 TL ile en çok harcama yapılan kalem yiyecek-içecek olduğu tespit edilmiştir. Arabistan'da ikamet eden katılımcıların toplam harcama tutarının 100.188 TL olduğu bu tutar içerisinde yiyecek içecek harcamaları 29.568 TL ile en yüksek paya sahip kalem olduğu, Gürcistan'da ikamet eden katılımcıların toplam harcamalarının 23.640TL olduğu ve bu rakam içerisinde 7.040 TL ile en çok harcama yapılan kalem yiyecek-içecek harcamaları olduğu saptanmıștır.

Azerbaycan'da ikamet edip Adana'yı ziyaret eden katılımcıların tatil süreçlerinde yaptıkları toplam harcama tutarı $18.820 \mathrm{TL}$ iken bu tutar içerisinde en yüksek harcama payı 4260 TL ile yiyecek içecek ve 4050 TL ile konaklama harcamaları olduğu, Katar'da ikamet eden katılımcıların toplam harcama tutarı 50.445 TL iken bu tutar içerisinde 10.780 TL ile yiyecek içecek harcamaları ve 10.140 TL giyim harcamalarının en yüksek paya sahip kalemler olduğu tespit edilmiştir. Mısır'da e ikamet eden katılımcıların toplam harcamaları 76.980 TL iken bu rakam içerisinde 18.205 TL ile en çok harcama yapılan kalemin konaklama olduğu, Fransa'da ikamet eden katılımcıların tatil süreçlerinde yaptıkları toplam harcama tutarı 173.705 TL iken bu tutar içerisinde en yüksek harcama payının 41.165 TL ile yiyecek içecek ve 35.975 TL ile eğlenceye ait olduğu saptanmıştır. Belçika'da ikamet eden katılımcıların harcamaları 149.960 TL iken bu rakam içerisinde 32.990 TL ile en çok harcama yapılan kalem yeme-içme olduğu, Almanya'da ikamet eden katılımcıların toplam harcama tutarı 49.405 TL iken bu tutar içerisinde en yüksek harcama 
payı 15.330 TL ile yiyecek içecek ve 11.665 TL ile eğlenceye ait olduğu saptanmiştır.

Tarım, sanayi, otomotiv veya tekstil sektörleri aracılığı ile kalkınma potansiyeli olmayan ancak zengin turizm arz kaynaklarına sahip destinasyonların ve hatta ülkelerin, bölgelerin kalkınmasında turizm sektörü bir politika olarak önem kazanmaktadır. Turizm sektörünün kalkınmada dinamik bir araç olarak kullanılması için ise bazı önlemlerin alınması gerekmektedir. Bu önlemleri Adana destinasyonu özelinde aşağıdaki şekilde sıralamak mümkündür:

- Adana'nın dengeli bir şekilde kalkınması, kalkınma strateji ve planlarına toplumun tüm kesimlerinin katılımıyla gerçekleşeceği göz ardı edilmemelidir.

- Şakirpaşa Havaalanının kent merkezinde kalması ve yurt içi ve yurtdışı taşımacılığın arttırılması gerekmektedir.

- Demiryolu taşımacılığındaki hız ve kalite sorunları çözülmelidir.

- Gelişmelerin yaşandığı gıda ve yiyecek sektörü özellikle kültürel turizm amacıyla gelen turist sayısı arttırıldığında daha fazla gelir getirir düzeye gelebilir.

- Adana'daki kamu ve özel sağlık kuruluşlarındaki gelişmeler sağlık turizmi amacıyla gelen turistlerin sayısını arttırabilir.

- Daha fazla yabancı turistin Adana'yı ziyaret etmesiyle birlikte; istihdam, gelir ve katma değer artacak, sürdürülebilir bir kalkınma gerçekleşebilecektir.

- Adana'nın tanıtımının yoğun bir şekilde yapılması gelmektedir.

- Adana'ya yönelik turları organize edecek ve düzenleyecek acentelerle bağlantılar kurulmalıdır.

- Adana'nın cazip bir hale getirilmesi için hem yerel hem de kamu otoritesinin, üniversiteler ile ortak hareket etmesi ve yeni projeleri hayata geçirmesi gereklidir.

- Adana'daki turistik tesislerde kalifiye elemanların istihdamı ile kaliteyi yakalamak mümkün olabilecektir.

- Adana'nın diğer destinasyonlara göre sahip olduğu farklı turizm ürünlerini ortaya koymalıdır.

- Adana'daki doğal güzellikler ön plana çıkarılarak eko turizm amacıyla gelen turistlerin sayısını arttırabilir.

Adana'nın doğal, tarihi ve kültürel güzellikleri ile turizme kazandırılması; bölgenin turizm payını arttıracak, doğal olarak bölge ekonomisi ve yeni istihdam olanaklarını geliştirecektir. $\mathrm{Bu}$ bağlamda bölgenin turizm destinasyonu olarak geliştirilmesi, ziyaretçilerin istek ve beklentilerini karşılamaya yönelik girişimlerin yapılması ve turizm değerlerinin turistik ürün haline getirilmesine yönelik çalışmalara ihtiyaç duyulmaktadır. Öte yandan bölgede ekoturizm, kuş gözlemciliği, kırsal turizm, sağlık turizmi, kongre turizmi, gastronomi turizmi gibi alternatif turizm alanlarında desteklenmesi bölgenin mevcut turizm değerlerinin farkındalık kazanmasında etkili olacaktır. 
Sonuç olarak Adana'nın mevcut değerlerinin turizm ile bütünleştirilerek arz edilmesi, Adana turizminin önünü açacak ve bölgeye ekonomik katkılar sunacaktır. Turizmin Adana'ya ekonomik katkıları bölgedeki ulaşım ağlarının, alt yapı ve üst yapının, turizm işletmelerinin, istihdamın ve bölgedeki diğer sektörlerin gelişimine de katkılar sağlayacaktır.

\section{KAYNAKÇA}

Adana Büyükşehir Belediyesi (t.y.), Ekonomi. http://www.adanabel.tr/ekonomi (Erş.Tar. 02.10.2017).

Adana İl Kültür ve Turizm Müdürlüğü. (t.y.). Turizm. http://www.adanakulturturizm.gov.tr (Erş.Tar. 02.10.2017).

Adana İl Kültür ve Turizm Müdürlügüu. (t.y.). Turizm. http://www.adanakulturturizm.gov.tr/TR,161748/turizm-isletme-belgelikonaklama-tesisleri.html Erş.Tar. 02.08.2017).

Adana Valiliği. (t.y.). Sanayi ve Ticaret. http://www.adana.gov.tr/sanayiticaret (Erş.Tar. 02.10.2017).

Adana Valiliği. (t.y.). Turizm. http://www.adana.gov.tr/?act=kt turizm (Erş.Tar. 14.04.2015).

BAHAR, O. (2007). Bölgesel Kalkınmada Turizm Sektörünün Ekonomik Açıdan Yeri ve Önemi. Muğla Üniversitesi Sosyal Bilimler Enstitüsü Dergisi, Güz(19).

ÇEKEN, H. (2008). Turizmin Bölgesel Kalkınmaya Etkisi Üzerine Teorik Bir inceleme. Afyon Kocatepe Üniversitesi IIIBF Dergisi, 10(2), 293-306.

ÇIMAT, A., \& BAHAR, O. (2003). Turizm Sektörünün Türkiye Ekonomisi İçindeki Yeri ve Önemi Üzerine Bir Değerlendirme. Akdeniz Universitesi Iktisadi ve Idari Bilimler Fakultesi Dergisi, 3(6).

DURGUN, A. (2006). Bölgesel Kalkınmada Turizmin Rolü: Isparta Örneği. Süleyman Demirel Üniversitesi, Sosyal Bilimler Enstitüsü, Yayımlanmamış Yüksek lisans Tezi.

KAYPAK, S. (2013). Yerel Kalkınmada Yeni Bir Anlayıș: Kentlerin Markalaşması (Hatay Marka Kent Örneği). Celal Bayar Üniversitesi, Sosyal Bilimler Enstitüsü, Yerel ve Bölgesel Kalkınma: Küresel ve Yerel Bakış Açıları, Manisa.

KIZILDEMİR, Ö. (2017). Turizm Endüstrisinin Ekonomik Etkilerinin Bölgesel Kalkınma Açısından Değerlendirilmesi: Adana Örneği. Yayınlanmamış Doktora Tezi. Sakarya: Sakarya Üniversitesi Sosyal Bilimler Enstitüsü.

Kültür ve Turizm Bakanlığı (2016).Turizm İstatistikleri. http://yigm.kulturturizm.gov.tr/ TR,9856/konaklama-istatistikleri.html (Erş.Tar. 14.05.2016).

Kültür ve Turizm Bakanlığı, (2007). Türkiye Turizm Stratejiler 2023 Eylem Planı 2007-2013. http://www.kulturturizm.gov.tr (Erş.Tar. 24.02.2017). TUİK (2016). Istihdam Rakamları. (Erş.Tar. 15 Eylül 2017). 
Türkiye Kalkınma Bankası A.Ș. (2016). Adana İli Potansiyel Yatırım Konuları Araştırması, Ocak, Ankara,

Türkiye Turizm Stratejisi-2023, www.resmigazete.gov.tr/eskiler/2007/03/20070302-17-1.doc (Erş.Tar. 2/08/2017).

UNWTO, (2014). Tourism Highlights. World Tourism Organization Publishing. Publishing.

UNWTO, (2016). Tourism Highlights. World Tourism Organization

Wikipedia. (t.y.). Adana İli. http://tr.wikipedia.org/wiki/Adana (Erş.Tar. 14.04.2015).

YAĞCI, Ö. (2007). Turizm Ekonomisi (2.Baskı b.). Ankara: Detay.

YAZICIOĞLU, Y., \& ERDOĞAN, S. (2004). SPSS Uygulamalı Bilimsel Araştırma Yöntemleri. Ankara: Detay Yayıncılık.

\section{Summary}

As one of the fastest growing industries in the world, tourism has significant impacts on economic development. For this reason, countries that give importance to their development also palace emphasis on tourism improvement. It is a known fact that tourism has contributions on both territorial and regional development. The role of tourism, especially in the context globalisation, cannot be underestimated. In this research, the effects of tourism have been studied by using tourism expenditures dataset of tourists that visit Adana.

Adana is the marketing and distribution center of Cukurova agriculture area where is famous with the production of cotton, wheat, soya bean, barley, grape and citrus fruit. Textile and leather industry are the major industries that constitute 29\% of Adana's production. Besides agriculture and textile Adana also has improved in the automotive industry. Temsa, the biggest company of Adana in the automotive industry, has more than 2,500 employees and produces 4,000 buses per year. Along with agriculture and industry, livestock also makes important contributions to the economy of Adana. Today, with exports exceeding 1 billion 700 million dollars, Adana is one of the leading cities of Turkey in economy, trade, industry and banking sector.

Adana, which has been on military and commercial roads since ancient times, has become an attractive place for various communities. This city has always been essential especially as a location between Anatolia, Mesopotamia and Eastern Mediterranean. With its convenient climate for four seasons, geographical location, transportation facilities, this city has been a sight of many civilizations through history. Thanks to its historical background, numerous historic monuments, antique cities, castles, natural beauties, handicrafts, culinary culture, climatic conditions, Adana has a good potential in terms of tourism. According to the data of 2016-2017, there are a total of 10.772 bed capacity with 
tourism and municipality certificates, 7 food and beverage operations, 129 travel agencies and 143 guides in Adana.

The aim of this study is to evaluate the role of tourism in the regional development of Adana. When the role of tourism in the development of a destination is examined, the expenditures of tourists visiting that region are considered. These reviews can influence tourism policy and planning for the future. In this context, the expenditures of the domestic and foreign tourists visiting Adana were examined in this study. Dataset was created from 600 participants, including 107 residents and 493 nonresidents. The research data were collected in November 2016. Expenditures made in Euro and Dollar have been converted into Turkish Liras at an approximate value based on the exchange rate between December 25, 2017, and January 5, 2018. ( $1 \$=3,8 \notin ; 1 €=4,5 \notin)$.

According to the results of the research, the total expenditure of 600 participants participating in their visit to Adana is £ 1,339,202 and the average expenditure per person is $¥$ 2232. Tourists that visit Adana mostly spent money for food and beverages. The total amount of money that spent on food and beverage is $¥ 321.523$ and it consists of $24 \%$ of total expenditures. When the average expenditures are analyzed according to the countries where the participants reside, the countries with the highest average per capita expenditure are France, Belgium, Netherlands, Arabia and Egypt. When evaluated in general, the number of tourists coming to Adana in 2017 is 1.094 .335 people and the average per capita expenditure in the research framework is $¥ 2232$. The result of multiplying the number of arriving tourists by the average per capita expenditure seems to have contributed directly to the Adana economy with approximately 2.44 billion $T L / 642$ million $\$(1 \$=3.8$ $\$$ ). This situation shows that tourism is effective for regional development of Adana that is one of the most developed cities of Turkey in terms of agriculture and industry. So it can be said that tourism may make significant contributions to regional development.

As a result, the integration of Adana's existing values with tourism may contribute to tourism and may provide economic contributions to the region. The economic contributions of tourism to Adana may also important for the development of transport networks, infrastructure and superstructure, tourism enterprises, employment and other sectors in the region. The development of tourism in the region makes sense not only for Adana but also Turkey. 